\title{
Barriers and Opportunities for the Implementation of Sustainable Farming Practices in Mediterranean Tree Orchards
}

\author{
Javier Calatrava ${ }^{1, *(\mathbb{D}}$, David Martínez-Granados ${ }^{1}\left(\mathbb{D}\right.$, Raúl Zornoza $\left.{ }^{2}{ }^{(}\right)$, Manuel González-Rosado ${ }^{3}{ }^{(}$, \\ Beatriz Lozano-García ${ }^{3}{ }^{-1}$, Manuela Vega-Zamora ${ }^{4}$ a and María Dolores Gómez-López ${ }^{2}$
}

1 Agricultural Economics Research Group, Escuela Técnica Superior de Ingeniería Agronómica, Universidad Politécnica de Cartagena, Paseo Alfonso XIII, 48, 30203 Cartagena, Spain; david.martinez@upct.es

2 Sustainable Use, Management, and Reclamation of Soil and Water Research Group, Department of Agricultural Engineering, Universidad Politécnica de Cartagena, Paseo Alfonso XIII 48, 30203 Cartagena, Spain; raul.zornoza@upct.es (R.Z.); lola.gomez@upct.es (M.D.G.-L.)

3 SUMAS Research Group, Department of Agricultural Chemistry, Soil Science and Microbiology, Faculty of Science, Agrifood Campus of International Excellence-ceiA3, University of Cordoba, 14071 Cordoba, Spain; mgrosado@uco.es (M.G.-R.); beatriz.lozano@uco.es (B.L.-G.)

4 Business Management, Marketing and Sociology Department, Campus Las Lagunillas s/n, University of Jaen, 23071 Jaén, Spain; mvega@ujaen.es

* Correspondence: j.calatrava@upct.es

Citation: Calatrava, J.;

Martínez-Granados, D.; Zornoza, R.; González-Rosado, M.; Lozano-García, B.; Vega-Zamora, M.; Gómez-López, M.D. Barriers and Opportunities for the Implementation of Sustainable Farming Practices in Mediterranean Tree Orchards. Agronomy 2021, 11, 821. https://doi.org/10.3390/ agronomy11050821

Received: 16 February 2021

Accepted: 16 April 2021

Published: 22 April 2021

Publisher's Note: MDPI stays neutral with regard to jurisdictional claims in published maps and institutional affiliations.

Copyright: (c) 2021 by the authors. Licensee MDPI, Basel, Switzerland. This article is an open access article distributed under the terms and conditions of the Creative Commons Attribution (CC BY) license (https:/ / creativecommons.org/licenses/by/ $4.0 /)$.

\begin{abstract}
This study identifies, through consultation with relevant stakeholders, low-input farming practices that can help to minimize the most pressing agronomic and environmental problems in some of the most relevant Mediterranean woody crops in Spain (almond, citrus, and olive) and enhance their sustainability. The results illustrate stakeholders' perception regarding how each cropping system could be oriented towards a more sustainable production. Despite each case study's particularities, there is consensus in the need for a shift towards the use of organic fertilizers, the maintenance of vegetation in the edges of plots and the use of integrated pest control strategies. On the contrary, stakeholders have selected different tillage and soil cover practices that are consistent with the characteristics and problems of each cropping system. This study also identifies relevant strengths and drawbacks for the implementation of low-input agricultural practices in each crop and study area. While stakeholders find the identified low-impact farming practices as easy and not costly, suggesting a significant potential for their successful implementation, the results also point out at the reduced knowledge of the practical benefits of some farming practices and the need for improved technical advice to foster the adoption of others.
\end{abstract}

Keywords: almond; citrus; olive; low-input agricultural practices; stakeholders assessment; multicriteria decision

\section{Introduction}

Spain is the country most severely threatened by desertification processes in the European Union [1]. In addition, the southern regions of Spain present the highest land degradation ratios [2], being some of the most threatened areas by the effects of climate change in the European Union [3,4]. Conventional intensive tillage practices are behind the severe degradation of large cropland areas in Europe [5,6]. Current cropping systems that use large amounts of external, non-renewable resources and cause environmental degradation are currently being questioned $[7,8]$.

The adaptation of agricultural systems to a sustainable farming management that promotes land restoration and prevents soil degradation and desertification is an essential strategy in a climate change scenario that suggests an increasing vulnerability of agricultural systems in the EU [9]. This greater vulnerability of agroecosystems is usually associated with the foreseen trend of increasing temperatures and drought occurrence and 
decreasing rainfall, especially in the Mediterranean basin [10,11]. Moreover, Mediterranean regions are particularly sensitive to these foreseen changes in water resources availability precisely due to their fragile environmental conditions [12].

In southern Spain, the cultivation of woody crops, such as olives, almonds and citrus, has considerable historical and cultural relevance [13-15]. These agroecosystems play a key role in the territory, both because of their spatial extension and their social, environmental and economic relevance [16]. The evolution in the management of these cropping systems, based on monocropping, conventional intensive tillage, the lack of cover crops, the excessive use of chemical inputs and the low biodiversity, has caused these woody crops to frequently be associated with degraded areas [17-19]. The persistent application over time of these crop management practices has led to both the physical and chemical deterioration of the soils where these woody crops are grown, leading to low levels of soil organic matter and low structural stability that promote important processes of soil erosion [20-22]. Because of these environmental damages, policy and social spheres are promoting dynamics oriented to the modification of agricultural management practices and the movement towards more sustainable agroecosystems, looking to harmonize economic profitability and environmental preservation [23]. To achieve this objective, both new techniques and farm management strategies and the involvement of farmers are key elements [24].

In many areas of southern and eastern Spain where Mediterranean woody crops such as olive, almond and citrus are grown, these crops face a problem of relatively low productivity and profitability. However, if properly restored and managed, these cropping systems have a high potential to become sustainable and be able to provide a large amount of ecosystem services, such as the conservation of landscapes and other natural and cultural heritage, the enhancement of biodiversity and the mitigation of climate change effects $[25,26]$. The improvement of environmental sustainability is a strategy that has been recently pointed out as optimal to achieve a more competitive agriculture in the European "From Farm to Fork Strategy" [27]. The low profitability and competitiveness of some agricultural productions is a major driver of the abandonment of traditional crops and of the resulting depopulation of rural areas. Under this scenario, the improvement of environmental sustainability implies an agriculture based on good agricultural practices that contribute to erosion control (minimization of runoff), climate change mitigation (carbon soil fixation), pollution control (minimization of polluting emissions from the use of agrochemicals), and the maintenance of soil fertility and the biodiversity (flora and fauna) associated with crops. In this sense, there is a social demand that is expressed through a greater willingness to pay for food that has been obtained through sustainable practices, increasing the economic benefit of marginal areas [28,29]. In addition to being a source of income and employment, environmental sustainability also contributes to mitigating the depopulation of rural areas, while contributing to generating public goods valued by society, both of an environmental nature (which we have already alluded) and of a territorial nature (maintenance of rural vitality, traditional agrarian landscapes and the associated agrarian heritage).

In this context, the main objective of this study is to identify, through consultation with relevant stakeholders, suitable low-input farming practices for some of the most relevant Mediterranean woody crops that can help to minimize their most pressing agronomic, environmental and socioeconomic problems and enhance their sustainability. The paper follows with a description of the three cropping systems considered in this study and the methodological approach used, which is based on a survey to stakeholders and multicriteria decision-making to identify the best alternatives, ending with the results and their discussion.

\section{Case Study Areas}

The study focuses on the most important Mediterranean woody crops in Spain, namely rainfed olive (Olea europaea, L.) and almond groves (Prunus dulcis, Mill.) and irrigated 
citrus crops (Citrus spp., L.). Woody crops account for 4.7 million hectares, representing a $28.4 \%$ of total cropland in Spain (Table 1). This percentage notably increases in Southern and Eastern regions of the country. The case study area for almond and citrus cropping systems is the Murcia Region in South East Spain (Figure 1), a Mediterranean semi-arid area where average annual temperature is $17.5^{\circ} \mathrm{C}$, potential evapotranspiration is 1300 $\mathrm{mm}$ year ${ }^{-1}$ and average rainfall is $231 \mathrm{~mm}$ year $^{-1}$. The case study area for olive groves is Andalusia, in South Spain (Figure 1), where average annual temperature is $17^{\circ} \mathrm{C}$, potential evapotranspiration is $916 \mathrm{~mm}_{\text {year }}{ }^{-1}$ and rainfall averages $645.7 \mathrm{~mm}_{\text {year }}{ }^{-1}$. Overall, the three woody crops considered in this study account for $72.6 \%, 70 \%$ and $97 \%$ of the area planted with woody crops in Spain, the Murcia Region and Andalusia, respectively.

Table 1. Area planted with the case study crops in Spain (2017, hectares).

\begin{tabular}{cccc}
\hline & Spain & Murcia & Andalusia \\
\hline TOTAL CROP LAND & $16,861,958$ & 441,103 & $3,628,317$ \\
\hline WOODY CROPS & $4,794,460$ & 194,208 & $1,932,416$ \\
\hline Almond & 633,562 & 76,363 & 191,642 \\
\hline Citrus & 294,258 & 38,582 & 83,683 \\
\hline Olive & $2,554,829$ & 20,428 & $1,596,717$ \\
\hline
\end{tabular}

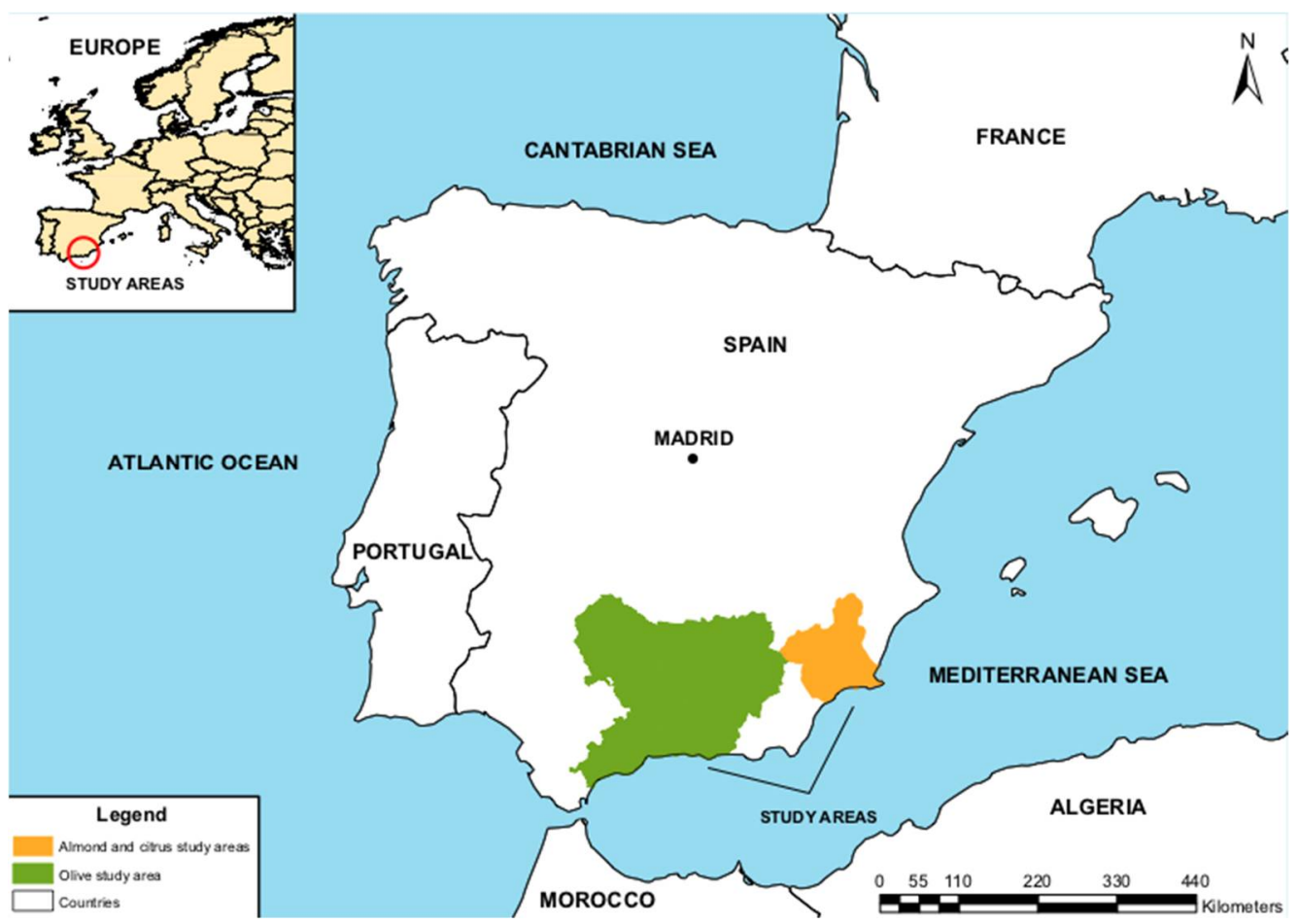

Figure 1. Location of case study areas in Southern Spain.

Olive is the most relevant crops in Spain, accounting for more than a half of the national area planted with woody crops, and $82.6 \%$ of the woody crops area in Andalusia (Table 1), where it is the most traditional crop associated with extensive Andalusian landscapes. About $22.8 \%$ of the area planted with olive orchards is irrigated [30]. Traditional extensive olive orchards were ecologically diverse agroecosystems. However, the huge expansion of the olive area since the 1980s, after the entrance of Spain in the UE, has led to the development of large areas of monoculture and a decreasing diversity. The generalization of intensive farming practices has done it a less ecologically sustainable crop. The most 
frequent farming practices include: several tillage operations in spring using disk harrows and cultivators and one tine harrow pass during summer; winter applications of urea in alternate years, right after harvesting; and the use of pesticides and broad-spectrum herbicides. On the bright side, the use of pruning residues as mulching is an increasingly used conservation practice [31]. At present, the main negative impacts associated with olive cultivation are related to soil erosion, depletion and diffuse pollution of groundwater resources, loss of biodiversity and deterioration of traditional landscapes [32].

Almond is a traditional crop in Mediterranean Spain, accounting for $13.2 \%$ of the Spanish woody crops area (Table 1). It mostly concentrates along the Mediterranean coast, where it is the major woody crop and has great social and economic importance in rural areas. In the Murcia Region, 39.3\% of the woody crop area is planted with almond trees. A majority of the almond area in Spain is non-irrigated $(86.3 \%)$, although the irrigated area is slightly increasing [30]. Traditional rainfed almond orchards are mostly located on steeped marginal lands, with high a risk of late frosts and low yields (120-150 kg ha-1), as it is the case of the predominant model in the Murcia Region and Andalusia. With more suitable soil and climate conditions, yields can reach about $500 \mathrm{~kg} \mathrm{ha}^{-1}$.

Citrus is also a traditional cropping system in Mediterranean Spain, the main citrus producer in the EU with 7.09 million tons per year. Although citrus accounts only for about $6 \%$ of the area planted with woody crops in Spain (Table 1), 95\% of the citrus area is concentrated in the irrigated areas of the Valencia Region, Andalusia and Murcia Region, along the Mediterranean coast. In the Murcia Region, the case study area, citrus orchards account for a $20 \%$ of the area planted with woody crops. Market globalization in currently imposing huge pressure over the Spanish citrus sector, where more competitive producing countries and the threat of new pests and diseases are compromising the health and profitability of Spanish citrus farms. Spanish citrus farms also suffer from problems derived from intense tillage practices, mineral fertilization, and the use of pesticides and herbicides. A more sustainable citrus cultivation is needed to face these problems and to achieve a greater profitability that allows for the continuity of Spanish citrus farms.

\section{Methodology}

\subsection{Survey to Stakeholders}

The perceptions of relevant stakeholders about the most adequate crop management alternatives to enhance sustainability in agroecosystems were gathered using a common questionnaire developed within the H2020 project DIVERFARMING. The questionnaire was adapted to the particularities of each of the three cropping systems based on a bibliographic review about diversified cropping systems and sustainable farming practices $[16,33]$.

The questionnaire was composed of four blocks of questions: (1) Stakeholder's characteristics (name, gender, type of stakeholder, affiliation, etc.); (2) Identification and assessment of the most relevant agro-environmental problems of each crop and area of study (choice from an open list), and assessment of the priority that they would give to possible actions that could be taken to tackle the previously identified problems (choice from an open list); (3) Identification of farming practices that the stakeholder considers as appropriate for the characteristics of their crop and area of study, choosing, as in the previous block, from a list of options that was open for the interviewee to propose additional options. For those farming practices that were not considered as suitable for each crop/study area, stakeholders were also asked to indicate the main reason for not selecting such practices; (4) Assessment of the effectiveness of farming practices to face the agro-environmental problems previously identified by the interviewee.

Five types of stakeholders were consulted: (1) farmers; (2) farm advisory services; (3) agricultural public administrations; (4) agricultural researchers; and (5) experts from NGOs with experience on farming. The interviewed stakeholders were participants in the participatory assessment process carried out within the DIVERFARMING H2020 project's activities. The survey was implemented online using the Survey Monkey surveying platform. 


\subsection{Multicriteria Assessment}

As each case study area has different agro-environmental problems, the evaluation of the effectiveness of agricultural practices was done qualitatively using linguistic labels. The stakeholders were first asked to select the most appropriate farming practices for their cropping system and region, and then to qualitatively assess their effectiveness in mitigating the agro-environmental problems in their study area. The analysis of their responses was done by establishing a ranking of effectiveness of farming practices using multiple criteria selection methods. The choice of the multi-criteria decision method to be used must also consider the need to convert the stakeholder's qualitative assessment into a quantitative assessment for its numerical treatment, e.g., by using standardized ordinal linguistic labels that have a numerical correlation to collect stakeholder's assessments in the questionnaire.

Multi-criteria alternative selection systems are defined by the following elements [34]:

$$
\{C, D, r, I, \prec\}
$$

where:

$C=\left\{C_{1}, \ldots, C_{j}, \ldots C_{m}\right\}$ are the $m$ different criteria used to compare alternatives. In this analysis, it was considered that the criteria $(C)$ were the decision-makers (in our case, the stakeholders responding to the survey).

$D=\left\{D_{1}, \ldots, D_{i}, \ldots, D_{n}\right\}$ are the $n$ alternatives considered as feasible in the survey (agricultural practices) that the decision-maker must assess qualitatively. Unlike in more complex decision systems, $C$ and $D$ are finite sets, what avoids problems of convergence, integrability and measurability.

$r: D \times C \rightarrow r$ is a function that generates a matrix in which each term corresponds to a reality associated with each alternative $D_{i}$ and criterion $C_{j}$ :

$$
\left(D_{i}, C_{j}\right) \rightarrow r\left(D_{i}, C_{j}\right)=r_{i j}
$$

$I$ is the set of linguistic labels used by the decision makers to assess each alternative for each criterion. $\prec$ are the preferences of the decision-makers with respect to the different alternatives considered in the decision.

The effectiveness of each alternative $\left(D_{i}\right)$ was assessed for each criterion, that is, each decision maker $\left(C_{j}\right)$ qualitatively evaluated each alternative using linguistic terms $(I)$ to express that effectiveness ( $r_{i j}$ values). The use of linguistic labels allows the decision maker to express his/her perception of the goodness of each alternative. The $r_{i j}$ values obtained configure the decision-making matrix that represent the preferences $(\prec)$ of the decision-makers with respect to the different alternatives. It is assumed that the decisionmaker is rational, in the sense of acting coherently with his/her preferences and objectives and his/her previous knowledge, and expressing them through these linguistic labels. More precisely, in this study, the importance of the criteria was obtained, through direct assignment, using a valuation scale with six levels (labels) that ranges between "Very low" (0) and "Very high" (5). For example, the question pattern used was "According to your criterion, the effectiveness of practice $Y$ for addressing environmental problem $X$ is:" (Very low, Low, Medium low, Medium high, High, Very high). Using a six-level scale is justified by the non-existence of possible neutral positions in the assessment of the severity of a problem or the effectiveness of a given farming practice, and by the need to prevent respondents without an opinion from using the middle point as a "save-the-face response" instead of using the "do not know/do not answer" option [35]. These standardized ordinal linguistic labels used to collect the stakeholder's qualitative assessments were converted to numerical correlated labels, which represent the corresponding quantitative assessment, using a 0 to 5 numerical scale where 0 corresponds to "very low/null" and 5 to "very high".

In this study, the definition of the multicriteria model was based on a group of agricultural practices/strategies that are the alternatives to be selected, the stakeholders' point of view that are based on their prior knowledge and preferences (criteria), and 
the corresponding assessment of the effectiveness of each alternative. The selection and assessment of alternatives was made in independent decision processes for each crop and area and for each stakeholder profile. The aggregation of the different types of stakeholders allowed us to obtain a single result of the priority ranking of farming practices for each crop and study area (group decision). In this case, each type of stakeholders was equally weighted in the group's decision. The mathematical calculation to obtain the preferences ranking of farming practices was carried out using the Order Preference Technique for Similarity with the Ideal Solution (TOPSIS) methodology developed by [36-38]. The TOPSIS methodology is based on the calculation of the geometric distance to the ideal solution, prioritizing the alternatives that are closer to the positive ideal solution (PIS) and further from the negative ideal solution (NIS). These proximity indices allow establishing a priority ranking of alternatives (i.e., agricultural practices) for each case study. Those practices with the highest ranking were selected as the most effective ones.

\section{Results and Discussion}

\subsection{Main Characteristics of Surveyed Stakeholders}

Table 2 presents the main characteristics of the surveyed stakeholders, including the number of respondents per type of stakeholder and their average age. The number of interviewees in the case of Andalusia doubles that of the Murcia Region case studies due to the greater geographical extension of both Andalusia and the olive producing areas. It must be also noted that many of the surveyed private technical advisors are also farmers, especially in the case of Andalusia, but have been considered as technical advisors.

Table 2. Characteristics of surveyed stakeholders.

\begin{tabular}{cccc}
\hline & $\begin{array}{c}\text { Almond } \\
\text { (Murcia Region) }\end{array}$ & $\begin{array}{c}\text { Citrus } \\
\text { (Murcia Region) }\end{array}$ & $\begin{array}{c}\text { Olive } \\
\text { (Andalusia) }\end{array}$ \\
\hline Number of respondents (female) & $21(1)$ & $22(4)$ & $43(9)$ \\
\hline Farmers & 9 & 9 & 3 \\
\hline Private technical advisors & 5 & 4 & 16 \\
\hline Public technical officers & 2 & 3 & 8 \\
\hline Researchers & 3 & 1 & 14 \\
\hline NGO representatives & 2 & $48.5(9.1)$ & 2 \\
\hline Average respondent's age & $50.1(9.6)$ & $45.5(7.7)$ & \\
\hline
\end{tabular}

Own elaboration. Standard deviation in parenthesis.

\subsection{Assessment of Agro-Environmental Problems and Priorities for Action}

The respondents were asked to qualitatively assess the gravity of several agro-environmental problems in the crop and area of study about which they are experts. Their qualitative answers were converted to a 0 to 5 scale (Table 3 ). The stakeholders' perception of the severity of agro-environmental problems is consistent with the specific nature of the agricultural systems analyzed (irrigated citrus in plains and slight slopes and rainfed olive and almond trees in more steeped areas). 
Table 3. Stakeholders' qualitative subjective assessment of the gravity of different problems in their area (measured on a 0 to 5 scale: 0 = very low /null, 5 = Very high).

\begin{tabular}{|c|c|c|c|c|c|c|c|c|c|}
\hline \multirow{2}{*}{ Problem Assessed } & \multicolumn{3}{|c|}{$\begin{array}{c}\text { Almond } \\
\text { (Murcia Region) }\end{array}$} & \multicolumn{3}{|c|}{$\begin{array}{c}\text { Citrus } \\
\text { (Murcia Region) }\end{array}$} & \multicolumn{3}{|c|}{$\begin{array}{c}\text { Olive } \\
\text { (Andalusia) }\end{array}$} \\
\hline & Median & Average & $\begin{array}{c}\text { St. } \\
\text { Dev. }\end{array}$ & Median & Average & $\begin{array}{c}\text { St. } \\
\text { Dev. }\end{array}$ & Median & Average & $\begin{array}{c}\text { St. } \\
\text { Dev. }\end{array}$ \\
\hline Soil pollution & 3.00 & 2.90 & 0.97 & 3.00 & 2.91 & 0.87 & 3.00 & 2.83 & 1.17 \\
\hline Water pollution & 3.00 & 3.05 & 1.16 & 3.00 & 2.91 & 1.06 & 3.00 & 2.98 & 1.16 \\
\hline Excessive use of machinery & 3.00 & 2.90 & 1.45 & 3.00 & 2.67 & 1.20 & 2.00 & 2.60 & 1.42 \\
\hline Excessive use of fertilizers & 4.00 & 3.48 & 1.21 & 3.00 & 3.50 & 0.96 & 3.00 & 3.10 & 1.23 \\
\hline Excessive use of pesticides & 4.00 & 3.48 & 1.12 & 3.00 & 3.32 & 1.09 & 3.00 & 3.36 & 1.25 \\
\hline Excessive use of water & 2.00 & 2.38 & 1.20 & 2.00 & 2.32 & 1.29 & 3.00 & 2.86 & 1.52 \\
\hline Soil degradation by erosion & 4.00 & 3.60 & 1.14 & 3.00 & 3.32 & 1.25 & 4.00 & 3.91 & 1.04 \\
\hline Loss of organic matter in soils & 4.00 & 3.76 & 0.94 & 3.00 & 3.32 & 1.29 & 4.00 & 4.14 & 1.03 \\
\hline Waterlogged soils & 2.00 & 2.05 & 1.40 & 2.00 & 2.10 & 1.37 & 2.00 & 1.69 & 1.14 \\
\hline Loss of biodiversity & 4.00 & 3.43 & 1.12 & 3.00 & 3.09 & 1.38 & 4.00 & 3.42 & 1.24 \\
\hline Landscape degradation & 4.00 & 3.57 & 1.03 & 3.00 & 2.95 & 1.46 & 3.00 & 3.19 & 1.31 \\
\hline $\begin{array}{c}\text { Loss of profitability / farm } \\
\text { abandonment }\end{array}$ & 4.00 & 3.57 & 1.16 & 4.00 & 3.48 & 1.21 & 3.00 & 3.30 & 1.19 \\
\hline
\end{tabular}

Own elaboration.

Table 3 shows that the decrease in the organic matter content of soils is perceived as the most severe agro-environmental problem in olive and almond trees of the areas of study, closely followed by soil erosion. Olive and almond are usually cultivated in areas with relatively low soil organic matter content, moisture and fertility, being well adapted to Mediterranean climates under rainfed agriculture [39]. The most common farming practice in these cropping systems is an intensive weed control through regular tillage and/or herbicides, which causes a decrease in soil organic matter due to the high mineralization rates and to the soil erosion that bare soils cause $[16,39,40]$. The torrential nature of rainfall events in Mediterranean areas, mostly concentrated in autumn after a long dry summer, positions soil erosion as a severe hazard, of special relevance in more steeped slopes, highly abundant in olive groves and almond orchards [16,31,41]. Although there is a perception about the severity of organic matter loss and erosion in this type of cropping systems, conventional management linked to monocultures with bare alleys is still dominant. Morugán-Coronado et al. [16] performed a meta-analysis on the effect of intercropping and sustainable management practices on crop yield and soil properties under Mediterranean orchards, and described that soil in the alleys still remains bare because farmers do not perceive that cover crops or reduced tillage practices increase crop yields and think that vegetation, either spontaneous or planted, compete with crops for nutrients and water, a major concern in areas with low water availability due to climate constraints. In addition, farmers also have the perception that a field with vegetated alleys is a "dirty" field that must be amended with tillage or herbicides [18,42]. Thus, as a general pattern, the problem is perceived, but no effective measures are being taken to properly solve it.

Similar relevance is given to the risk of farm abandonment and to landscape degradation in almond farms in the Murcia Region, whereas the latter problem is assessed as less severe in Andalusian olive orchards. The loss of biodiversity is also acknowledged also as a highly relevant problem in both almond and olive farming. Olive groves and almond orchards have been traditionally cultivated in the Mediterranean basin for centuries, reaching even high mountain range altitudes. These crops are often integrated with forest areas into the Mediterranean rural landscape, maintaining high biodiversity spots [15,43]. A significant share of almond orchards has been abandoned during the last decades because of their low profitability and the competition with other countries such as USA, leading to the degradation of marginal lands and traditional landscapes [44]. On the contrary, the extension of olive groves has significantly increased during the last decades, mainly in southern Spain, breaking up forest soils, with the subsequent landscape degradation by presence of olive monocultures with bare soils [40,43]. This process started during the 1990s, mostly driven by the EU subsidies to olive production that were in force at that time [45]. 
The current simplification of the groves and orchards with extended monocultures and/or land abandonment has led also to the loss of biodiversity. Agricultural intensification commonly entails the loss of landscape diversity and farmland biodiversity $[46,47]$. It is important to highlight that erosion rates under Mediterranean climate are extreme on some lithologies such as marls (highly abundant in the Mediterranean basin), and since most soils from abandoned orchards were kept bare, erosion led to the loss of the most fertile surface layers, leading the current marginal lands with intense piping/gullying [48-50].

In citrus orchards, the most relevant agro-environmental problems for stakeholder are the excessive fertilization and the risk of farm abandonment due to the reduced crop profitability in recent years. The excessive use of fertilizers is assessed similarly in both almond and citrus crops in the Murcia Region, but less severely in Andalusian olive producing areas. Mediterranean citrus plantations, traditionally cultivated in valleys and flats with abundant water endowments, expanded during the last century in response to an increasing demand from Northern European countries. This process was fostered by technological developments that allowed the intensive exploitation of groundwater resources and the adoption of more efficient irrigation technologies, such as drip irrigation. As a result, a new agricultural system emerged based on an intensive use of capital, water, energy and nutrients and high production costs [42] that could only be compensated with high selling prices. Thus, the high price volatility in recent years and the increasing competition of non-European producers has significantly eroded citrus profitability and increased the risk of farm abandonment. Citrus growth is directly related to irrigation and fertilization to achieve profitable harvests, and this use of fertilization has caused increases in production costs, but also pollution of soil and water by nitrogen leaching and runoff as nitrate [51,52]. Nitrogen losses by leaching can be significant (50-150 kg ha ${ }^{-1}$ year $\left.^{-1}\right)$, especially if $\mathrm{N}$ fertilization exceeds the crop's needs [53]. In the case of almond trees, although their nutritional requirements are lower than those of citrus, $\mathrm{N}$ fertilization is always associated to a risk of pollution.

The excessive application of pesticides also appears as a severe problem in all three crops and areas of study. The use of herbicides is generalized in the three crops at stake, mostly in citrus orchards and olive groves, to avoid the growth of weeds which could compete for nutrients and mostly water with the cash crop [16]. The same problem is detected with the use of fungicides, bactericides and insecticides to control frequent diseases and pests, such as Phytophtora spp., Penicillium spp., Aonidiella aurantii, Ceratitis capitata, Aphis spiraecola and Aphis gossypii in citrus, Prays oleae, Bactrocera oleae, Saissetia oleae, Spilocea oleagina and Pseudomonas savastanoi in olives or Polystigma amygdalinum, Thyrostroma carpophilum, Monilia laxa and Taphrina deformans in almonds [54-56]. The use of fertilizers and pesticides is closely related to other potential problems also recognized by the stakeholders as less severe problems: soil and water pollution. When pesticides are applied to trees, a fraction of the product sprayed is lost and deposits either on the soil or drifts away from the site [57].

As it was expected for relatively dry areas, soil waterlogging is barely assessed as a serious problem in all three areas. Other potential problems, such as the excessive use of agricultural machinery, are also perceived as less severe problem by the surveyed stakeholders. Machinery in orchards is used for tilling to control weeds and break out the surface crust of the soil to favor gas exchange and water infiltration, plant protection, pruning and harvest. It is true that this perception of excessive use of machinery has been also treated in many scientific papers, suggesting that no-tillage or minimum tillage systems could have the same crop yields with decreased negative environmental impacts, such as greenhouse gas emissions, biodiversity loss and soil compaction, since tillage it is a practice with potential reduction in Mediterranean orchards [5,58,59]. However, in semiarid areas, no-tillage can have detrimental effects on crop yields, and it is recommended to avoid this practice and replace it by minimum tillage [16].

Once the stakeholders had assessed the severity of agro-environmental problems, they were asked to qualitatively value the priority that they give to different actions that can 
be taken to tackle those problems. Their qualitative answers were converted to a 0 to 5 scale (Table 4). Their answers are, in general, consistent with the previous identification of relevant problems.

Table 4. Stakeholders' qualitative subjective assessment of the priority of different action objectives in their area (measured on a 0 to 5 scale; $0=$ very low $/$ null, 5 = Very high).

\begin{tabular}{|c|c|c|c|c|c|c|c|c|c|}
\hline \multirow{2}{*}{ Actions } & \multicolumn{3}{|c|}{$\begin{array}{c}\text { Almond } \\
\text { (Murcia Region) }\end{array}$} & \multicolumn{3}{|c|}{$\begin{array}{c}\text { Citrus } \\
\text { (Murcia Region) } \\
\end{array}$} & \multicolumn{3}{|c|}{$\begin{array}{c}\text { Olive } \\
\text { (Andalusia) }\end{array}$} \\
\hline & Median & Average & $\begin{array}{l}\text { St. } \\
\text { Dev. }\end{array}$ & Median & Average & $\begin{array}{l}\text { St. } \\
\text { Dev. }\end{array}$ & Median & Average & $\begin{array}{l}\text { St. } \\
\text { Dev. }\end{array}$ \\
\hline $\begin{array}{l}\text { Increase carbon sequestration in soil } \\
\text { and arboreal biomass }\end{array}$ & 4.00 & 3.67 & 1.50 & 4.00 & 3.75 & 1.21 & 4.00 & 3.79 & 1.00 \\
\hline Increase soil fertility & 4.00 & 4.29 & 0.78 & 4.00 & 3.91 & 1.23 & 4.00 & 3.51 & 1.16 \\
\hline Improve the soil structure & 4.00 & 4.19 & 0.87 & 4.00 & 3.82 & 1.18 & 4.00 & 3.73 & 1.12 \\
\hline Increase biodiversity & 4.00 & 4.15 & 0.99 & 4.00 & 3.86 & 1.21 & 4.00 & 3.86 & 1.10 \\
\hline Reduce erosion & 4.00 & 4.40 & 0.68 & 4.00 & 3.91 & 1.23 & 5.00 & 4.47 & 0.93 \\
\hline Reduce energy consumption & 4.00 & 4.10 & 0.85 & 4.00 & 3.71 & 1.19 & 4.00 & 3.58 & 1.28 \\
\hline Reduce flooding in fields & 4.00 & 2.76 & 2.05 & 3.00 & 2.68 & 1.62 & 2.00 & 2.00 & 1.29 \\
\hline Increase crop yields & 4.00 & 3.90 & 1.33 & 4.00 & 3.33 & 1.65 & 3.00 & 3.19 & 1.16 \\
\hline Increase farm profitability & 4.00 & 4.00 & 1.12 & 5.00 & 4.21 & 1.23 & 4.00 & 3.93 & 1.33 \\
\hline Modernization of agriculture & 4.00 & 3.55 & 1.64 & 4.00 & 3.95 & 1.24 & 4.00 & 3.60 & 1.20 \\
\hline Conserve traditional landscapes & 5.00 & 4.25 & 1.12 & 4.00 & 3.82 & 1.22 & 4.00 & 4.00 & 0.88 \\
\hline Recover traditional crops & 4.00 & 3.60 & 1.47 & 4.00 & 3.36 & 1.36 & 3.00 & 3.16 & 1.40 \\
\hline
\end{tabular}

Table 4 shows that the surveyed stakeholders give the highest priority to actions targeted towards reducing soil erosion in both olive and almond trees of the areas of study. The stakeholders in both areas also coincide in considering the conservation of traditional landscapes as the second priority for action. Stakeholders in the Murcia Region also give a high importance to improving soil structure and soil fertility and to increasing biodiversity in almond crops, while these are considered as of a lesser priority, although still relevant, for Andalusian olive-producing areas. These responses are aligned with those in Table 3 related to the gravity of different problems, selecting those actions directly involved in tackling those main problems, giving coherence to the responses. Stakeholders assume that in rainfed orchards in sloped landscapes with high erodible materials low soil organic matter content and poor structure, the essential action to face this situation is to reduce soil loss and keep the traditional landscape in mosaic between forest areas with high biodiversity as agro-cultural heritage. Thus, stakeholders consider the traditional olive groves and almond orchards as essential part of the Mediterranean heritage, which must be protected to maintain the delivery of the ecosystem services associated [5,60], but implementing actions towards erosion control and soil quality improvement. In this line, [61] analyzed people's willingness to pay for the conservation of olive groves in South Spain and the value they give to the ecosystem services that olive groves provide. A majority of respondents to the survey were willing to pay for the conservation of the traditional olive groves within natural forest systems, being cultural and regulating ecosystem services the most valued ones. In addition, [62] demonstrated that preserving a heterogeneous habitat of high quality in the surroundings of almond orchards may help to maintain a stable fruit production as a consequence of the stability of pollination services associated to a heterogeneous landscape.

In the case of citrus, the main priority for action identified is increasing farm profitability, which is also considered as a relevant issue for almond and the second priority for olive. This aspect is important since many families depend on farming and on the productivity of the cultivated orchards. Hence, stakeholders are concerned about the problem of losing profitability and the need to enhance it so that Mediterranean orchards provides stabilized incomes. As previously commented, this issue is more valued in citrus because production 
costs under this farming system are higher owing to water, energy and nutrient needs, far higher than those needed for almonds or olives.

\subsection{Identification of the Most Adequate Farming Practices for Each Crop/Study Area}

The surveyed stakeholders were asked to indicate which farming practices they consider as potentially implementable according to the characteristics of their crop and area of study. Each respondent chose from a list of farming practices, although respondents could also propose other practices not included in the proposed list. Their responses are summarized in Table 5 . For those farming practices that stakeholders do not consider as suitable for each crop/study area, they were also asked to indicate the main reason for not selecting such practices, reasons that are summarized in the Appendix A (Tables A1 and A3).

Table 5. Identification of adequate farming practices for each crop in each study area (percentage of respondents identifying each practice as adequate).

\begin{tabular}{|c|c|c|c|}
\hline Farming Practice & $\begin{array}{c}\text { Almond } \\
\text { (Murcia Region) }\end{array}$ & $\begin{array}{c}\text { Citrus } \\
\text { (Murcia Region) }\end{array}$ & $\begin{array}{c}\text { Olive } \\
\text { (Andalusia) }\end{array}$ \\
\hline Tillage without heavy implements & 60.0 & 58.8 & 46.5 \\
\hline Tillage according to level curves & 70.0 & 58.8 & 34.9 \\
\hline Minimum tillage & 40.0 & 41.2 & 51.2 \\
\hline No tillage with herbicides & 25.0 & 23.5 & 27.9 \\
\hline No tillage without herbicides (with brush cutter) & 40.0 & 70.6 & 67.4 \\
\hline No tillage or minimum tillage with grazing & 25.0 & 0.0 & 44.2 \\
\hline Mulching (with crushed pruning offcuts, reeds, ...) & 70.0 & 76.5 & 86.0 \\
\hline Maintain vegetation cover (natural or cover crops) & 40.0 & 52.9 & 93.0 \\
\hline Maintain strips of vegetation between lines & 60.0 & 52.9 & 93.0 \\
\hline Construction of erosion barriers or margins without vegetation & 25.0 & 0.0 & 2.3 \\
\hline Construction of erosion barriers or margins with vegetation & 45.0 & 52.9 & 41.9 \\
\hline Maintain natural vegetation on plot's edges & 85.0 & 58.8 & 62.8 \\
\hline Installing hedges on the edges of the plots & 75.0 & 64.7 & 46.5 \\
\hline Contribution of organic matter/manure & 95.0 & 82.4 & 83.7 \\
\hline Combination of mineral and organic fertilizers & - & 47.1 & - \\
\hline Use of green manure & 65.0 & 70.6 & 55.8 \\
\hline Use of biostimulants and biofertilizers & 65.0 & 58.8 & 39.5 \\
\hline Precision agriculture to optimize fertilization & - & 64.7 & - \\
\hline Integrated pest control & 70.0 & 82.4 & 93.0 \\
\hline Crop combinations & - & 41.2 & - \\
\hline $\begin{array}{l}\text { Design keylines (channels/ditches to drive and make use of } \\
\text { rainwater) }\end{array}$ & 50.0 & 29.4 & 32.6 \\
\hline Irrigating, if necessary & - & - & 55.8 \\
\hline Controlled irrigation & - & 76.5 & - \\
\hline Regulated deficit irrigation & - & 47.1 & - \\
\hline Subsurface irrigation (in root) & - & 41.2 & - \\
\hline Micro-sprinkling & - & 11.8 & - \\
\hline Use of plastics & 5.0 & 11.8 & 0.0 \\
\hline
\end{tabular}

Own elaboration. 
If we look at tillage practices, we find significant differences between crops and areas. In the case of almond production in the Murcia Region, more stakeholders choose contour tillage and tillage with lighter implements against reduced tillage or no tillage options. We need to keep in mind the climatic conditions of the region and the typical landscape in which almond trees are grown, generally under rainfed systems. We are in a region with semiarid Mediterranean climate, with structural water scarcity all year, but frequent highly intense rainfall episodes of $>100 \mathrm{~L} \mathrm{~m}^{-2}$ accumulated in $12 \mathrm{~h}$ mostly during autumn. Orchards are located in terraces and slopes in soils developed mostly over limestones, marls or colluviums. Thus, the main need in this scenario is to control erosion, as indicated by the responses to questions in Table 4 . A promising option is to plough perpendicularly to the slope to control runoff $\left(90^{\circ}\right.$ tillage direction). Indeed, it has been reported in literature that applying $90^{\circ}-135^{\circ}$ tillage directions to slopes can be an important strategy for soil conservation [63]. Furthermore, furrows generated with this tillage strategy favors the retention of water, essential in semiarid environments. Alvarez-Mozos et al. [64] showed that contour tillage provided larger soil water retention by precipitation than tillage in the terrain aspect direction. However, the increment in water retention between contour tillage and tillage in the aspect direction was severely reduced as the slope gradient increased. Light implements reduce the weight of the machinery and so soil compactness, essential to improve the soil structure, which is also a priority for stakeholders (Table 4). Contrarily, no-tillage or reducing tillage frequency is not generally supported in the region because of the general perception that not breaking the surface crust of the soil hampers gas exchange and water retention in the soil and thus reduces crop yield. Morugán-Coronado et al. [16] reported in their meta-analysis on the effect of intercropping and tillage type on crop yield in fruit orchards under Mediterranean conditions, including mostly olives, grapevines and almonds, that crop yields with no/reduced tillage and alley cropping tended to be lower than monocultures with conventional tillage in those areas with $<470 \mathrm{~mm}$ of mean annual precipitation and $>5.5$ of mean annual temperature. Above this threshold of moisture and below this threshold of temperature, no/reduced tillage and alley cropping increased crop yield compared to monocultures. Therefore, farmers' perception that no tillage or reduced tillage can reduce soil moisture and consequently water availability for the trees seems to be important in more arid and warmer areas.

The results for citrus are similar but no tillage without herbicides is chosen by more respondents than any other tillage alternative. Although respondents from almonds and citrus case studies belong to the same region, unlike most almond production, citrus are always irrigated. As such, citrus stakeholders are not so concerned about the competence between alley vegetation and the cash crop, and most of them perceive no tillage with brush cutter as a suitable option to manage citrus orchards. Research has shown the benefits of reduced and no-tillage for the delivery of ecosystem services, with increases in soil organic matter, the improvement in soil structure and water retention capacity, increase in microbial community size and activity and decrease in greenhouse gas emissions [65-68]. Furthermore, stakeholders are aware of the positive effects of keeping weeds or cover crops in the alleys instead of using herbicides, since vegetated alleys can increase soil organic matter, fertility, water retention capacity and biological activity [42]. In the case of Andalusian olives, no tillage without application of herbicides and mechanical control of weeds is the practice most chosen by respondents, aligned with the positive effects commented above. Surprisingly, and contrarily to the case of the Murcia Region, more respondents chose minimum tillage than contour tillage or the use of light tillage implements. We think that the reason can be connected to the different climatic conditions in both areas. Although the Region of Murcia is mostly semiarid with mean annual precipitation below $300 \mathrm{~mm}$, in northern Andalusia where olive groves are majoritarian, mean annual precipitation ranges between $450-600 \mathrm{~mm}$. Thus, the awareness about water competition and the need to keep most of the water for the cash crop is not so high, and alternatives as minimum tillage or no-tillage are perceived as positive. An interesting result concerning no tillage is that stakeholders in all three cropping systems clearly prefer the use of brush cutter for the 
mechanical control of weeds to the application of herbicides that could have negative and persistent effects on the environment. This response coincides with those in Tables 3 and 4, which show that most stakeholders are concerned with an excessive use of pesticides and soil/water pollution.

The reasons given by stakeholders for not choosing the different tillage practices are varied and differ from one crop to another (Tables A1 and A3). However, there are also relevant similarities. The most frequent reason for not choosing the different tillage options is that the respondents think that they are not adequate for the characteristics of the corresponding area of study and crop. In this sense, no-tillage or minimum tillage has been selected as not adequate for the area of study, mainly due to the climatic constraints, as explained above, so they think tillage is necessary to increase soil aeration and water retention. Indeed, [69] reported that under Mediterranean semiarid climate, some tillage in rainfed almond orchards is required to maintain optimal crop production by breaking soil compactness, confirming this concerned expressed by stakeholders. In the case of the combination of minimum/no tillage with cattle grazing, many stakeholders also indicate that they do not consider it a traditional practice in the area as the major reason for not choosing it as adequate. In rainfed crops (almond and olive), some stakeholders also point out at the incompatibility of certain tillage alternatives with other farming practices. Last, in the case of olive orchards, an important share of the stakeholders points to the lack of profitability of no tillage with application of herbicides as the main reason for not considering this practice as adequate.

Regarding practices related to soil cover to reduce soil erosion, mulching is the most voted practice amidst stakeholders in the Murcia Region for both almond and citrus, whereas vegetation cover and vegetation strips are slightly more preferred for Andalusian stakeholders. However, in the case of almond, more stakeholders clearly chose vegetation strips than cover crops or natural vegetation cover. The rationale for preferring mulching to vegetation strips and vegetation strip to cover crops is likely to be related to the competition for water with the main crop, as discussed before. The arid conditions of the Region of Murcia lead respondents to select mulching to cover soil and avoid evaporation or vegetation strips, which occupy a small proportion of the orchard's area and compete less for water than cover crops that occupy the entire area. Indeed, the use of mulching has been reported effective to increase water retention capacity by soil and decrease evaporation and erosion rate $[18,70]$.

There is a relatively high consensus in all three areas with respect to the most adequate alternative for establishing barriers to erosion runoff. In the case of rainfed crops, maintaining natural vegetation in the edges of plots of land and installing hedges are the most preferred options. However, in the case of olive farms, the alternative of natural vegetation notably stands out above the rest. In the case of citrus, the differences between the different type of barriers proposed is minimum. The main reasons given by stakeholders that do not find the different types of erosion barriers proposed as adequate are their inadequateness for the characteristics of the agricultural systems, their high cost and their lack of profitability. Thus, it seems that stakeholders replied thinking on the costs of installing erosion barriers rather than on the environmental benefit despite identifying erosion as one of the most important threats of the agroecosystems (Table 3). Stone terraces have been traditional in the Mediterranean agroecosystems linked to olive and almond production until the adoption of mechanized agriculture $[48,49]$. Nowadays, terraces are not kept, and new fields are broken up generating moderate or even steep slopes without the adoption of any erosion control measures, despite the high erosion rates measured in the Mediterranean basin. Despite respondents selecting the priority of taking measures against erosion and conserving the traditional landscape, the installation of erosion barriers such as ancient stone terraces is not supported, which seems, at first sight, contradictory. Moreno-de-las-Heras et al. [48] reported in their meta-analysis that the abandonment of traditional terraces in Mediterranean regions had severe geomorphological problems such as intense processes of surface erosion, piping and gullying. Thus, economic restrains 
with construction of stone barriers and difficulties for the return of the investment must lie behind this response. The maintenance of natural vegetation in the margins of the plots or making hedges is far cheaper and easier to make and conserve but can also be effective to control erosion. Several studies have demonstrated the positive effect of vegetation barriers to reduce soil erosion and runoff, increase sediment retention, provide habitats for auxiliary fauna and improve aesthetical values [71-73].

With respect to fertilization practices, there is a clear consensus in choosing the application of organic matter/manure as the most adequate one. Although the use of green manure and biostimulants and biofertilizers are chosen by about half of the stakeholders, the use of manure significantly stands above the rest. Most scientific studies highlight the advantages of organic fertilization, as compared to inorganic fertilization, in terms of increasing soil health and carbon sequestration in Mediterranean orchards without reducing crop yields [16]. Organic fertilization is associated with a significant increase in soil organic carbon and nitrogen with respect to inorganic fertilization due to the continuing application of organic matter to the soil, which improves soil structure and fertility and is associated with a greater biological activity in the soil [74-77]. Those stakeholders that do not consider the use of green manure as adequate think that is not an effective practice or that is not traditional in their area. In the case of almond and olive crops, several stakeholders also find it an expensive farming practice. Green manure involves the incorporation of cover crops into the soil. The only cost of green manure is the acquisition of seeds (normally a mixture of legumes, cereals, and brassicas) and machinery. The latter should be rented/acquired in many cases for sowing, since farmers from orchards do not usually have sowing adapters, but incorporation is performed with traditional tillage implements. Thus, the only limitation we identify with the adoption of green manure should be the sowing period owing to the lack of the proper machinery. However, the literature review continuously shows the positive effects of green manure in orchards, with decrease of erosion rate, increase soil organic matter and foster soil carbon sequestration and improve soil structure and fertility, being compatible with cover crops and minimum tillage $[17,41,78,79]$.

Similar reasons are given by stakeholders that do not view the use of biostimulants and biofertilizers as adequate practices, with several stakeholders, especially for olive, pointing out the need for skilled technical advice. These types of products can reduce the application of chemical fertilizers because most of the microorganisms included in the products can solubilize soil nutrients, enhancing crop yield and quality [80-82]. This practice may avoid the excessive use of traditional fertilizers which may pollute soil and water [83]. However, the use of biostimulants and biofertilizers is still too novel and not widely used by farmers because they do not really understand their mechanisms and have not seen evidence about their higher economic and environmental benefits compared to chemical fertilizers [84]. In this line, [85] point out that the use of biofertilizers by farmers requires that the benefits of their use are unambiguously demonstrated.

With respect to the use of precision agriculture techniques to optimize fertilization in citrus, stakeholders point at their inadequacy for citrus orchards and the need for technical advice as the main reasons for not recommending them. Precision agriculture involves a high degree of farm technification and a significant investment in equipment/materials and training. However, farmers should get familiar with farming innovation since the enhancement of the agricultural sector's competitiveness requires the generalized adoption of those innovations that foster agricultural productivity and sustainability [86]. One of the most promising fields of innovation in agriculture is the digitalization of farming, as it can provide farmers with continuous and detailed information on their production processes [87]. Benefits of precision farming that have been proved at the on-farm level include increasing crop yield and quality, reducing the environmental and climate impacts of farming, increasing farm resilience and soil health and decreasing crop production costs $[87,88]$. However, not all farmers are prone to adopt precision agriculture and, indeed, previous studies have also shown that European farmers are hesitant to adopt smart 
farming technologies [89,90]. Kernecker et al. [89] identified in a survey to farmers that the most common adoption barriers were the investment costs and the lack of perception of the benefits of precision farming technologies, a result that is aligned with the responses received in this study.

There is also a large consensus in the three areas regarding the adequacy of integrated pest control, which is of compulsory implementation in Spain since 2014. The few stakeholders that did not choose this technology gave varied reasons, with some prevalence of the complexity of implementing it and the need for, and cost of, technical advice. Thus, there is a consensus that there is a need to reduce the use of synthetic pesticides in agriculture and, at the same time, to adopt other cultural practices and tools for crop protection, so chemicals are only used when it is strictly necessary, in line with environmental protection.

Turning to water management practices, the design and construction of keylines to drive and use rainwater is only considered as an adequate practice for half of respondents in the case of almond and a third of them in the case of citrus and olive. Reasons given are its little effectiveness and inadequacy for the area characteristics and its high cost and reduced profitability. In the case of olive, several respondents point out at the complexity of this practice. Keylines are nature-based solutions for land management. They describe a system of soil cultivation, designed by the land manager with the aim to harvest rainwater and so conserve soil moisture and prevent erosion [91]. Their higher support in rainfed almond orchards under semiarid climate was expected, since these structures can help harvest water from rain, increase water content in the soil, and reduce erosion. Since some training and advice is needed to properly design the keylines across plots, not all respondents in more water-abundant areas support the use of this strategy.

In the case of citrus production in the Murcia Region, stakeholders were asked about different irrigation strategies and technologies. While half of them signaled at controlled irrigation, only a third considered regulated deficit irrigation or root subsurface irrigation as a suitable farming alternative. The most frequent reason for rejecting micro-sprinkling and subsurface irrigation is that they are not considered as adequate practices for the area, while the most frequent reason for not using regulated deficit irrigation is its complexity and the need for skilled technical advice. Again, these replies raise the need for training among farmers to bring down the barriers detected for the adoption of some practices. High qualification and skills are limitations for adopting some measures which have proven to be positive in research. Instead of fostering innovation adoption by training and advice, there is a trend to avoid those practices that require high investment efforts both due to acquisition of technology and personnel training. Water scarcity in the Mediterranean is foreseen to be aggravated due to climate change [4], posing the need for the adoption of new irrigation strategies, such as regulated deficit irrigation, in order to optimize water and energy use while maintain agricultural production in water-scarce areas [92]. Regulated deficit irrigation strategies consist of reducing water supply during the crop's non-critical phenological periods and satisfying the crop's water requirements during critical periods, while maintaining crop production [93]. Regulated deficit irrigation appears to be a feasible alternative to reduce water consumption in agriculture and the associated environmental impacts, but also to reduce production costs and to improve the competitiveness of agricultural production, with the drawback of needing some initial investment and the support of qualified technicians [94].

Last, barely any respondent in any of the study areas considered the use of plastic as an adequate farming practice, for not being suitable for the characteristics of the cropping systems or for being too expensive and not profitable. This response in also aligned with those highlighting priority actions to avoid soil and water pollution and the recovery of traditional landscapes. The use of plastics is highly aggressive with the environment if not properly managed, with pollution of soil and water and decrease aesthetic value of the agro-ecosystem [95]. Indeed, in the last years, there is aware rising about the relevance of a circular approach to plastic waste reduction in agriculture by emphasizing various end-of-life alternatives already available with the use of bioplastics [96]. 


\subsection{Assessment of the Effectiveness of Farming Practices for Each Crop/Study Area}

The survey asked stakeholders to qualitatively assess the effectiveness for tackling the agro-environmental problems in their crop/study area of the farming practices that he/she considers as adequate. It must be noted that this question was only answered for any given farming practice by those stakeholders that chose such practice as adequate for the crop/area of study. Table 6 shows the order of preferences for farming practices resulting from the TOPSIS multicriteria analysis. A higher ranking means that this practice is considered as being more effective by more surveyed stakeholders. The ranking ordering of farming practices provided by stakeholders' answers (Table 6) is similar to the one presented in Table 4, although there are some differences and the farming practices selected as adequate for their crop and area by more stakeholders are not always the ones assessed as more effective.

Table 6. Stakeholders' qualitative assessment of the effectiveness of each of the farming practices in order to face the agro-environmental problems in the crops and areas of study (ranking of preferences from the multicriteria assessment).

\begin{tabular}{|c|c|c|c|}
\hline Farming Practice & $\begin{array}{c}\text { Almond (Murcia } \\
\text { Region) }\end{array}$ & $\begin{array}{l}\text { Citrus (Murcia } \\
\text { Region) }\end{array}$ & $\begin{array}{c}\text { Olive } \\
\text { (Andalusia) }\end{array}$ \\
\hline Tillage without heavy implements & 0.495 & 0.65 & 0.45 \\
\hline Tillage according to level curves & 0.715 & 0.41 & 0.43 \\
\hline Minimum tillage & 0.470 & 0.39 & 0.49 \\
\hline No tillage with herbicides & 0.218 & 0.20 & 0.197 \\
\hline No tillage without herbicides (with brush cutter) & 0.351 & 0.41 & 0.69 \\
\hline No tillage or minimum tillage with grazing & 0.329 & 0.00 & 0.48 \\
\hline Mulching (with crushed pruning offcuts, reeds, ... ) & 0.509 & 0.52 & 0.82 \\
\hline Maintain vegetation cover (natural or cover crops) & 0.282 & 0.43 & 0.61 \\
\hline Maintain strips of vegetation between lines & 0.562 & 0.47 & 0.53 \\
\hline Construction of erosion barriers or margins without vegetation & 0.193 & 0.00 & 0.00 \\
\hline Construction of erosion barriers or margins with vegetation & 0.437 & 0.37 & 0.44 \\
\hline Maintain natural vegetation on plot's edges & 0.683 & 0.41 & 0.56 \\
\hline Installing hedges on the edges of the plots & 0.548 & 0.47 & 0.42 \\
\hline Addition of organic amendments & 0.726 & 0.76 & 0.76 \\
\hline Combination of mineral and organic fertilizers & - & 0.38 & - \\
\hline Use of green manure & 0.575 & 0.76 & 0.57 \\
\hline Use of biostimulants and biofertilizers & 0.426 & 0.66 & 0.48 \\
\hline Precision agriculture to optimize fertilization & - & 0.46 & - \\
\hline Integrated pest control & 0.682 & 0.75 & 0.96 \\
\hline Crop combinations & - & 0.58 & - \\
\hline Design keylines for rainwater & 0.352 & 0.41 & 0.44 \\
\hline Irrigating, if necessary & - & - & 0.49 \\
\hline Controlled irrigation & - & 0.48 & - \\
\hline Regulated deficit irrigation & - & 0.33 & - \\
\hline Subsurface irrigation (in root) & - & 0.41 & - \\
\hline Micro-sprinkling & - & 0.19 & - \\
\hline Use of plastics & 0.203 & 0.17 & - \\
\hline
\end{tabular}

Own elaboration. Respondents were asked to assess the effectiveness to face the agri-environmental problems in their area of each of the farming practice that each of them had previously selected as adequate for the corresponding study crop. The farming practices with the highest scores are highlighted in bold font. 
Looking at tillage practices, contour tillage is assessed as the most effective alternative for almond production in the Murcia Region, far above reduced tillage alternatives. In the case of citrus production, stakeholders find tillage using lighter implements as the most effective tillage option. No tillage without herbicides, despite of being selected as adequate by more respondents than any other tillage alternative, is perceived as less effective. In the case of Andalusian olives, no tillage without application of herbicides and mechanical control of weeds is perceived as the most effective option. These differences are consistent with the particularities of each cropping systems. Again, no tillage with the application of herbicides is perceived as less effective than no tillage with mechanical weed control, with similar rankings in the three cases (Table 6).

Regarding practices related to soil cover, there are slight changes with respect to Table 5. While mulching is the most voted practice amidst stakeholders in the Murcia Region for both almond and citrus, the most effective practices are maintaining vegetation strips between lines in almond crops and mulching in citrus orchards. However, the ranking differences are small. In the case of olive, mulching is the preferred alternative. Indeed, it is the second preferred of all farming practices for olive after integrated pest control. Cover crops/vegetation are also among the five most effective farming practices for Andalusian stakeholders, but far behind mulching. The most effective alternatives for reducing erosion runoff are maintaining natural vegetation in the edges of plots of land for almond and olive crops, and hedges in the case of citrus orchards. In the case of almond, maintaining natural vegetation in the edges of plots is considered the third most effective farming practice in the ordering of stakeholders' preferences.

With respect to the fertilization practices, the application of organic matter/manure is considered as the most effective one, with similar rankings in the three cases, together with green manure in the case of citrus crops. The use of green manure also receives a relatively high ranking in the case of almond and olive crops. There is also a large consensus regarding the effectiveness of integrated pest control in all the three areas, with the highest rankings in the case of citrus and olive crops. On the contrary, the farming practices related to water management receive relatively low scores in all cases. Controlled irrigation in citrus production and supplementary irrigation in olives are considered as the most effective ones.

The farming practices with the highest scores in each case study are highlighted in bold font in Table 6, while Table 7 summarizes the most effective practice per type based on the results from Table 6, illustrating the perception of the interviewed stakeholders regarding how each cropping system could be oriented towards a more sustainable production.

Table 7. Most effective farming practices according to the stakeholders' qualitative assessment (based on the ranking of preferences from the multicriteria assessment).

\begin{tabular}{|c|c|c|c|}
\hline Type of Farming Practice & Almond (Murcia Region) & Citrus (Murcia Region) & Olive (Andalusia) \\
\hline Tillage & $\begin{array}{l}\text { Tillage according to level } \\
\text { curves }(0.715)\end{array}$ & $\begin{array}{l}\text { Tillage without heavy } \\
\text { implements }(0.65)\end{array}$ & $\begin{array}{l}\text { No tillage without herbicides } \\
\text { (with brush cutter) }(0.69)\end{array}$ \\
\hline Soil cover & $\begin{array}{l}\text { Maintain strips of vegetation } \\
\text { between lines }(0.562)\end{array}$ & $\begin{array}{l}\text { Mulching (with crushed } \\
\text { pruning offcuts, } \\
\text { reeds, ... ) (0.52) }\end{array}$ & $\begin{array}{l}\text { Mulching (with crushed } \\
\text { pruning offcuts, } \\
\text { reeds, ... (0.82) }\end{array}$ \\
\hline Soil erosion control & $\begin{array}{l}\text { Maintain natural vegetation } \\
\text { on the plot's edges }(0.683)\end{array}$ & $\begin{array}{l}\text { Installing hedges on the edges } \\
\text { of the plots }(0.47)\end{array}$ & $\begin{array}{l}\text { Maintain natural vegetation on } \\
\text { the plot's edges }(0.56)\end{array}$ \\
\hline Fertilization & $\begin{array}{l}\text { Addition of organic } \\
\text { amendments }(0.726)\end{array}$ & $\begin{array}{c}\text { Addition of organic } \\
\text { amendments / use of green } \\
\text { manure }(0.76)\end{array}$ & $\begin{array}{l}\text { Addition of organic } \\
\text { amendments }(0.76)\end{array}$ \\
\hline Pest control & Integrated pest control (0.682) & Integrated pest control $(0.75)$ & Integrated pest control (0.96) \\
\hline
\end{tabular}




\section{Concluding Remarks}

The present article identifies, through consultation with relevant stakeholders, lowinput farming practices that can help to minimize the most pressing agronomic and environmental problems in some of the most relevant Mediterranean woody crops and enhance their sustainability. The questionnaire used to survey stakeholders was designed to make them think carefully about the specific problems of each study area and about the feasibility of the possible solutions. We believe that this has helped for a realistic and practical identification of the most suitable farming practices.

The results presented illustrate the perception of the interviewed stakeholders regarding how each cropping system could be oriented towards a more sustainable production. Overall, and despite the differences in each case study, there is a clear consensus about the need for a shift of fertilization practices towards the use of organic sources (crop residues, compost, manure, etc.), the maintenance of some type of vegetation in the edges of plots and integrated pest control strategies. On the contrary, stakeholders selected different tillage and soil cover practices, such as mulching or cover crops, which are consistent with the characteristics and identified problems of each agricultural system. This suggests that policies aiming to foster a more sustainable agriculture should be based on a stakeholders and system-oriented approach that allow the identification of the most suitable farming practices for each crop and area, as these can differ significantly between cropping systems and pedoclimatic areas.

Although interviewed stakeholders gave priority to the conservation of soils, biodiversity and landscapes, there is a permanent consideration of farm profitability, not only in its identification as a priority objective, but also on the assessment of farming practices. Stakeholders' perceptions of farming practices are notably permeated by their perceived effect on farm profitability. Such concern with the economic pillar of sustainable farming is shown both in the consideration of the effect of farming practices on farm costs/profits and in the perceived lack of profitability of some alternatives, such as non-productive soil conservation structures (hedges, terraces, etc.), what results in the preference for other soil conservation options (mulching, vegetation strips or cover crops) that are perceived as less costly. Thus, focusing on those low-input farming practices that contribute to farm profitability appears as a key issue for a more successful policymaking. However, farming practices that implicate non-productive investments, which are not profitable for farmers but can generate significant ecosystem services to society, must not be left aside and should be subsidized when necessary and opportune.

In addition to identifying the most effective farming practices, this study allows to identify relevant strengths and drawbacks for the implementation of low-input agricultural practices in the crops and areas of study. A major strength came from the fact that the identified low-impact farming practices are easy to learn and to implement by farmers, do not require large investments in new machinery and are not costly. This suggests that there is a significant potential for their adoption. However, the study also highlights the reduced knowledge and perception of the practical benefits of some farming practices and the need for improved technical advice to foster the adoption of some promising alternatives, such as green manure, the use of biostimulants and biofertilizers and regulated deficit irrigation techniques, to cite some examples. Policy efforts in this sense, should focus on a more effective public extension, based on active training and demonstrative activities that inform relevant stakeholders, about the practical potential of more sustainable farming practices.

To end, some limitations of our study must be highlighted in order to guide future related research. These arise mostly from the survey-based approach taken. Survey questionnaires must be detailed enough to provide the required information but not too exhaustive and complex to prevent respondents from losing interest and abandoning the survey or leaving unanswered questions. This does not allow for a deeper discussion with each stakeholder and generates the risk of not collecting all the information that could be relevant for the objectives of the study. The use of personal semi-structured interviews with each stakeholder could provide more detailed and insightful results. In our case, 
we partly addressed this issue by confirming the validity of the results in participatory discussion groups with stakeholders in each case study area. Another related limitation is that farming practices were considered individually rather than as a part of a production process in which they present synergies or conflict with each other. Future research should aim at the identification and assessment of suitable combinations of farming practices for each cropping system and pedoclimatic area.

Author Contributions: Conceptualization, M.D.G.-L., R.Z. and J.C.; methodology, M.D.G.-L., R.Z., J.C. and D.M.-G.; software, M.D.G.-L. and D.M.-G.; formal analysis, J.C., M.D.G.-L. and D.M.-G.; investigation, J.C., R.Z., M.D.G.-L., D.M.-G., M.G.-R., B.L.-G. and M.V.-Z.; data curation, D.M.-G.; writing—original draft preparation, J.C., R.Z., M.D.G.-L., D.M.-G., M.G.-R., B.L.-G. and M.V.-Z.; writing-review and editing, J.C.; visualization, J.C. and D.M.-G.; supervision, M.D.G.-L.; project administration, R.Z.; funding acquisition, R.Z. All authors have read and agreed to the published version of the manuscript.

Funding: This research was funded by the European Commission through the DIVERFARMING H2020 project (grant agreement 728003).

Institutional Review Board Statement: The study was conducted according to the ethical guidelines of the DIVERFARMING H2020 project (grant agreement 728003), which were approved by the Ethics Committee of the Universidad Politécnica de Cartagena and the European Commission (funder of DIVERFARMING).

Informed Consent Statement: Informed consent was obtained from all subjects involved in the study.

Data Availability Statement: Data is available at https://zenodo.org/communities/diverfarming (accessed on 1 February 2021).

Conflicts of Interest: The authors declare no conflict of interest. The funders had no role in the design of the study; in the collection, analysis, or interpretation of data; in the writing of the manuscript, or in the decision to publish the results.

\section{Appendix A}

Table A1. Reason given by each respondent for not selecting each farming practice as adequate for almond tree crop in the Murcia Region (percentage of respondents that did not choose it).

\begin{tabular}{|c|c|c|c|c|c|c|c|c|c|}
\hline \multirow{2}{*}{ Farming Practice } & \multicolumn{9}{|c|}{ Reason } \\
\hline & A & B & $\mathrm{C}$ & D & $\mathbf{E}$ & $\mathbf{F}$ & G & $\mathbf{H}$ & I \\
\hline Tillage without heavy implements & 19.0 & 28.6 & 4.8 & & 4.8 & 19.0 & & 9.5 & 14.3 \\
\hline Tillage according to level curves & 7.7 & 30.8 & 7.7 & 3.8 & 11.5 & 11.5 & & 11.5 & 15.4 \\
\hline Minimum tillage & 20.0 & 25.0 & 15.0 & 5.0 & & 20.0 & & & 15.0 \\
\hline No tillage with herbicides & 10.3 & 34.5 & 6.9 & & 3.4 & 10.3 & & 3.4 & 31.0 \\
\hline $\begin{array}{l}\text { No tillage without herbicides (with } \\
\text { brush cutter) }\end{array}$ & 7.7 & & 23.1 & 7.7 & & 15.4 & & 23.1 & 23.1 \\
\hline No tillage or minimum tillage with grazing & 8.7 & 13.0 & 39.1 & 4.3 & 13.0 & 13.0 & & & 8.7 \\
\hline $\begin{array}{l}\text { Mulching (with crushed pruning } \\
\text { offcuts, reeds ... ) }\end{array}$ & 20.0 & 40.0 & & & & 40.0 & & & \\
\hline $\begin{array}{l}\text { Maintain vegetation cover (natural or } \\
\text { cover crops) }\end{array}$ & 33.3 & & & & 33.3 & 33.3 & & & \\
\hline Maintain strips of vegetation between lines & 6.7 & 13.3 & 6.7 & 6.7 & 6.7 & 33.3 & & 6.7 & 20.0 \\
\hline $\begin{array}{l}\text { Construction of erosion barriers or margins } \\
\text { without vegetation }\end{array}$ & 10.0 & 30.0 & 17.5 & 2.5 & & 5.0 & & 15.0 & 20.0 \\
\hline $\begin{array}{l}\text { Construction of erosion barriers or margins } \\
\text { with vegetation }\end{array}$ & & 13.0 & 26.1 & 4.3 & & 4.3 & & 21.7 & 30.4 \\
\hline $\begin{array}{l}\text { Maintain natural vegetation on the } \\
\text { plot's edges }\end{array}$ & 21.4 & 7.1 & 28.6 & 7.1 & & 7.1 & & & 28.6 \\
\hline
\end{tabular}


Table A1. Cont.

\begin{tabular}{|c|c|c|c|c|c|c|c|c|c|}
\hline \multirow{2}{*}{ Farming Practice } & \multicolumn{9}{|c|}{ Reason } \\
\hline & A & B & $\mathrm{C}$ & $\mathbf{D}$ & $\mathrm{E}$ & $\mathbf{F}$ & G & $\mathbf{H}$ & I \\
\hline Installing hedges on the edges of the plots & 9.1 & 13.6 & 31.8 & 4.5 & & 9.1 & 4.5 & 4.5 & 22.7 \\
\hline Contribution of organic matter/manure & & 20.0 & & & & & 20.0 & 60.0 & \\
\hline Use of green manure & 17.6 & 17.6 & 23.5 & & 5.9 & & & 17.6 & 17.6 \\
\hline Use of biostimulants and biofertilizers & 20.8 & 12.5 & 12.5 & 25.0 & 4.2 & & & 8.3 & 16.7 \\
\hline Integrated pest control & & & & & 50.0 & & & & 50.0 \\
\hline $\begin{array}{l}\text { Design keylines (channels/ditches to } \\
\text { drive rainwater) }\end{array}$ & 7.4 & 25.9 & 14.8 & 3.7 & 11.1 & 3.7 & 3.7 & 18.5 & 11.1 \\
\hline Irrigating, if necessary & 11.8 & 17.6 & & 5.9 & 11.8 & & 11.8 & 23.5 & 17.6 \\
\hline Use of plastics & 9.8 & 39.0 & 17.1 & 2.4 & & 7.3 & 2.4 & 9.8 & 12.2 \\
\hline
\end{tabular}

Own elaboration. (A) Limited effectiveness; (B) Practice is not adequate for the characteristics of the area; (C) It is not a traditional practice in the area; (D) It is complex/difficult to implement without technical advice; (E) It is complex/difficult to carry out even with technical advice; (F) This practice is not compatible with other farming practices; $(\mathrm{G})$ This practice requires a high investment cost; (H) The cost of carrying out this practice is high; (I) The benefits of this practice do not outweigh its costs.

Table A2. Reason given by each respondent for not selecting each farming practice as adequate for citrus crops in the Murcia Region (percentage of respondents that did not choose it).

\begin{tabular}{|c|c|c|c|c|c|c|c|c|c|}
\hline \multirow{2}{*}{ Farming Practice } & \multicolumn{9}{|c|}{ Reason } \\
\hline & A & B & C & $\mathbf{D}$ & $\mathbf{E}$ & $\mathbf{F}$ & G & $\mathbf{H}$ & I \\
\hline Tillage without heavy implements & 14.3 & 57.1 & 14.3 & & & & & 14.3 & \\
\hline Tillage according to level curves & 14.3 & 57.1 & 14.3 & 14.3 & & & & & \\
\hline Minimum tillage & 10.0 & 50.0 & 30.0 & & & 10.0 & & & \\
\hline No tillage with herbicides & 23.1 & 23.1 & 30.8 & 7.7 & & 7.7 & & & 7.7 \\
\hline $\begin{array}{l}\text { No tillage without herbicides (with } \\
\text { brush cutter) }\end{array}$ & 33.3 & 33.3 & 33.3 & & & & & & \\
\hline No tillage or minimum tillage with grazing & 17.6 & 35.3 & 41.2 & & & 5.9 & & & \\
\hline $\begin{array}{l}\text { Mulching (with crushed pruning } \\
\text { offcuts, reeds, ... ) }\end{array}$ & 25.0 & 25.0 & & & & & & 25.0 & 25.0 \\
\hline $\begin{array}{l}\text { Maintain vegetation cover (natural or } \\
\text { cover crops) }\end{array}$ & 11.1 & 22.2 & 11.1 & 11.1 & 11.1 & 11.1 & & 11.1 & 11.1 \\
\hline Maintain strips of vegetation between lines & 12.5 & 25.0 & 12.5 & 12.5 & & & 12.5 & 12.5 & 12.5 \\
\hline $\begin{array}{l}\text { Construction of erosion barriers or margins } \\
\text { without vegetation }\end{array}$ & 5.9 & 41.2 & 23.5 & & & & 5.9 & 17.6 & 5.9 \\
\hline $\begin{array}{l}\text { Construction of erosion barriers or margins } \\
\text { with vegetation }\end{array}$ & & 50.0 & 12.5 & & & & 12.5 & 25.0 & \\
\hline $\begin{array}{l}\text { Maintain natural vegetation on the } \\
\text { plot's edges }\end{array}$ & & 37.5 & 25.0 & & & 25.0 & 12.5 & & \\
\hline Installing hedges on the edges of the plots & 16.7 & 16.7 & 16.7 & & & & 16.7 & 16.7 & 16.7 \\
\hline Contribution of organic matter/manure & & 50.0 & 25.0 & & & & & 25.0 & \\
\hline $\begin{array}{l}\text { Combination of mineral and } \\
\text { organic fertilizers }\end{array}$ & & 33.3 & 11.1 & 11.1 & 11.1 & & & 22.2 & 11.1 \\
\hline Use of green manure & 20.0 & 40.0 & 40.0 & & & & & & \\
\hline Use of biostimulants and biofertilizers & 28.6 & 14.3 & 14.3 & 14.3 & 14.3 & & & & 14.3 \\
\hline
\end{tabular}


Table A2. Cont.

\begin{tabular}{|c|c|c|c|c|c|c|c|c|c|}
\hline \multirow{2}{*}{ Farming Practice } & \multicolumn{9}{|c|}{ Reason } \\
\hline & A & B & $\mathrm{C}$ & $\mathbf{D}$ & E & $\mathbf{F}$ & G & $\mathbf{H}$ & I \\
\hline $\begin{array}{l}\text { Precision agriculture to optimize } \\
\text { fertilization }\end{array}$ & & 50.0 & 16.7 & 16.7 & 16.7 & & & & \\
\hline Integrated pest control & & 25.0 & 25.0 & 50.0 & & & & & \\
\hline Crop combinations & & 30.0 & 40.0 & & 10.0 & & 10.0 & & 10.0 \\
\hline $\begin{array}{c}\text { Design keylines (channels/ditches to drive } \\
\text { rainwater) }\end{array}$ & 16.7 & 33.3 & 8.3 & 8.3 & 8.3 & & & 8.3 & 16.7 \\
\hline Controlled irrigation & 20.0 & 20.0 & & 40.0 & & 20.0 & & & \\
\hline Regulated deficit irrigation & & 22.2 & 22.2 & 44.4 & 11.1 & & & & \\
\hline Subsurface irrigation (in root) & 20.0 & 40.0 & 10.0 & 10.0 & 10.0 & & & & 10.0 \\
\hline Micro-sprinkling & 13.3 & 46.7 & 13.3 & 6.7 & 13.3 & & & & 6.7 \\
\hline Use of plastics & 13.3 & 33.3 & 20.0 & & & & 13.3 & 20.0 & \\
\hline \multicolumn{10}{|c|}{$\begin{array}{l}\text { Own elaboration. (A) Limited effectiveness; (B) Practice is not adequate for the characteristics of the area; (C) It is not a traditional practice } \\
\text { in the area; (D) It is complex/difficult to implement without technical advice; (E) It is complex/difficult to carry out even with technical } \\
\text { advice; (F) This practice is not compatible with other farming practices; }(\mathrm{G}) \text { This practice requires a high investment cost; (H) The cost of } \\
\text { carrying out this practice is high; (I) The benefits of this practice do not outweigh its costs. }\end{array}$} \\
\hline \multirow{2}{*}{ Farming Practice } & \multicolumn{9}{|c|}{ Reason } \\
\hline & A & B & $\mathrm{C}$ & D & E & $\mathbf{F}$ & G & $\mathbf{H}$ & $\mathbf{I}$ \\
\hline Tillage without heavy implements & 19.0 & 28.6 & 4.8 & & 4.8 & 19.0 & & 9.5 & 14.3 \\
\hline Tillage according to level curves & 7.7 & 30.8 & 7.7 & 3.8 & 11.5 & 11.5 & & 11.5 & 15.4 \\
\hline Minimum tillage & 20.0 & 25.0 & 15.0 & 5.0 & & 20.0 & & & 15.0 \\
\hline No tillage with herbicides & 10.3 & 34.5 & 6.9 & & 3.4 & 10.3 & & 3.4 & 31.0 \\
\hline $\begin{array}{l}\text { No tillage without herbicides (with } \\
\text { brush cutter) }\end{array}$ & 7.7 & & 23.1 & 7.7 & & 15.4 & & 23.1 & 23.1 \\
\hline No tillage or minimum tillage with grazing & 8.7 & 13.0 & 39.1 & 4.3 & 13.0 & 13.0 & & & 8.7 \\
\hline $\begin{array}{l}\text { Mulching (with crushed pruning } \\
\text { offcuts, reeds ... ) }\end{array}$ & 20.0 & 40.0 & & & & 40.0 & & & \\
\hline $\begin{array}{l}\text { Maintain vegetation cover (natural or } \\
\text { cover crops) }\end{array}$ & 33.3 & & & & 33.3 & 33.3 & & & \\
\hline Maintain strips of vegetation between lines & 6.7 & 13.3 & 6.7 & 6.7 & 6.7 & 33.3 & & 6.7 & 20.0 \\
\hline $\begin{array}{l}\text { Construction of erosion barriers or margins } \\
\text { without vegetation }\end{array}$ & 10.0 & 30.0 & 17.5 & 2.5 & & 5.0 & & 15.0 & 20.0 \\
\hline $\begin{array}{l}\text { Construction of erosion barriers or margins } \\
\text { with vegetation }\end{array}$ & & 13.0 & 26.1 & 4.3 & & 4.3 & & 21.7 & 30.4 \\
\hline $\begin{array}{l}\text { Maintain natural vegetation on the } \\
\text { plot's edges }\end{array}$ & 21.4 & 7.1 & 28.6 & 7.1 & & 7.1 & & & 28.6 \\
\hline Installing hedges on the edges of the plots & 9.1 & 13.6 & 31.8 & 4.5 & & 9.1 & 4.5 & 4.5 & 22.7 \\
\hline Contribution of organic matter/manure & & 20.0 & & & & & 20.0 & 60.0 & \\
\hline Use of green manure & 17.6 & 17.6 & 23.5 & & 5.9 & & & 17.6 & 17.6 \\
\hline
\end{tabular}


Table A3. Cont.

\begin{tabular}{|c|c|c|c|c|c|c|c|c|c|}
\hline \multirow{2}{*}{ Farming Practice } & \multicolumn{9}{|c|}{ Reason } \\
\hline & A & B & $\mathrm{C}$ & $\mathrm{D}$ & $\mathbf{E}$ & $\mathbf{F}$ & $\mathrm{G}$ & $\mathbf{H}$ & I \\
\hline Use of biostimulants and biofertilizers & 20.8 & 12.5 & 12.5 & 25.0 & 4.2 & & & 8.3 & 16.7 \\
\hline Integrated pest control & & & & & 50.0 & & & & 50.0 \\
\hline $\begin{array}{c}\text { Design keylines (channels/ditches to drive } \\
\text { rainwater) }\end{array}$ & 7.4 & 25.9 & 14.8 & 3.7 & 11.1 & 3.7 & 3.7 & 18.5 & 11.1 \\
\hline Irrigating, if necessary & 11.8 & 17.6 & & 5.9 & 11.8 & & 11.8 & 23.5 & 17.6 \\
\hline Use of plastics & 9.8 & 39.0 & 17.1 & 2.4 & & 7.3 & 2.4 & 9.8 & 12.2 \\
\hline
\end{tabular}

Own elaboration. (A) Limited effectiveness; (B) Practice is not adequate for the characteristics of the area; (C) It is not a traditional practice in the area; (D) It is complex/difficult to implement without technical advice; (E) It is complex/difficult to carry out even with technical advice; (F) This practice is not compatible with other farming practices; $(\mathrm{G})$ This practice requires a high investment cost; (H) The cost of carrying out this practice is high; (I) The benefits of this practice do not outweigh its costs.

\section{References}

1. Prăvălie, R.; Patriche, C.; Bandoc, G. Quantification of land degradation sensitivity areas in Southern and Central Southeastern Europe. New results based on improving DISMED methodology with new climate data. Catena 2017, 158, 309-320. [CrossRef]

2. MAPAMA. Perfiles Ambientales de España 2016: Protección del Suelo y Procesos de Degradación en España; MAPAMA: Madrid, Spain, 2017.

3. Brilli, L.; Lugato, E.; Moriondo, M.; Gioli, B.; Toscano, P.; Zaldei, A.; Leolini, L.; Cantini, C.; Caruso, G.; Gucci, R.; et al. Carbon sequestration capacity and productivity responses of Mediterranean olive groves under future climates and management options. Mitig. Adapt. Strat. Glob. Chang. 2018, 24, 467-491. [CrossRef]

4. IPCC. Climate Change 2013: The Physical Science Basis. Contribution of Working Group I to the Fifth Assessment Report of the Intergovernmental Panel on Climate Change; Stocker, T.F., Qin, D., Plattner, G.-K., Tignor, M., Allen, S.K., Boschung, J., Nauels, A., Xia, Y., Bex, V., Midgley, P.M., Eds.; Cambridge University Press: Cambridge, UK; New York, NY, USA, $2013 ;$ p. 1535.

5. Almagro, M.; de Vente, J.; Boix-Fayos, C.; García-Franco, N.; Melgares de Aguilar, J.; González, D.; Solé-Benet, A.; MartínezMena, M. Sustainable land management practices as providers of several ecosystem services under rainfed Mediterranean agroecosystems. Mitig. Adapt. Strat. Glob. Chang. 2016, 21, 1029-1043. [CrossRef]

6. Gucci, R.; Caruso, G.; Bertolla, C.; Urbani, S.; Taticchi, A.; Esposto, S.; Servili, M.; Sifola, M.I.; Pellegrini, S.; Pagliai, M.; et al. Changes of soil properties and tree performance induced by soil management in a high-density olive orchard. Eur. J. Agron. 2012, 41, 18-27. [CrossRef]

7. Baudron, F.; Giller, K.E. Agriculture and nature: Trouble and strife? Biol. Conserv. 2014, 170, 232-245. [CrossRef]

8. Ohyama, T. The Role of Legume-Rhizobium Symbiosis in Sustainable Agriculture. In Legume Nitrogen Fixation in Soils with Low Phosphorus Availability; Sulieman, S., Tran, L.S., Eds.; Springer: Cham, Switzerland, 2017; pp. 1-20. [CrossRef]

9. European Union. Regulation (EU) No 1307/2013 of the European Parliament and of the Council of 17 December 2013 Establishing Rules for Direct Payments to Farmers Under Support Schemes within the Framework of the Common Agricultural Policy and Repealing Council Regulation; European Union: Brussels, Belgium, 2013.

10. Lionello, P.; Abrantes, F.; Gacic, M.; Planton, S.; Trigo, R.; Ulbrich, U. The climate of the Mediterranean region: Research progress and climate change impacts. Reg. Environ. Chang. 2014, 14, 1679-1684. [CrossRef]

11. Lionello, P.; Scarascia, L. The relation between climate change in the Mediterranean region and global warming. Reg. Environ. Chang. 2018, 18, 1481-1493. [CrossRef]

12. Rubio, J.L.; Recatalá, L. The relevance and consequences of Mediterranean desertification including security aspects. In Desertification in the Mediterranean Region. A Security Issue; NATO Security Through Science Series; Kepner, W.G., Rubio, J.L., Mouat, D.A., Pedrazzini, F., Eds.; Springer: Dordrecht, The Netherlands, 2006; Volume 3, pp. 113-165.

13. Infante Amate, J. ¿Quién Levantó los Olivos? Historia de la Especialización Olivarera en el sur de España (S. XVIII-XX); Ministerio de Agricultura, Alimentación y Medio Ambiente: Madrid, Spain, 2014.

14. Lima Cueto, F.J.; Gómez Moreno, M.L.; Blanco Sepúlveda, R. El olivar de montaña y la conservación del suelo en la transición de la economía orgánica a la industrial: El caso de Sierra de las Nieves (Málaga), 1940. Ager. Rev. Estud. Despoblación Desarro. Rural. Depopulation Rural Dev. Stud. 2017, 23, 97-128. [CrossRef]

15. Zornoza, R.; Guerrero, C.; Mataix-Solera, J.; Scow, K.; Arcenegui, V.; Mataix-Beneyto, J. Changes in soil microbial community structure following the abandonment of agricultural terraces in mountainous areas of Eastern Spain. Appl. Soil Ecol. 2009, 42, 315-323. [CrossRef] [PubMed]

16. Morugán-Coronado, A.; Linares, C.; Gómez-López, M.D.; Faz, Á.; Zornoza, R. The impact of intercropping, tillage and fertilizer type on soil and crop yield in fruit orchards under Mediterranean conditions: A meta-analysis of field studies. Agric. Syst. 2020, 178, 102736. [CrossRef] 
17. Almagro, M.; Martínez-Mena, M. Litter decomposition rates of green manure as affected by soil erosion, transport and deposition processes, and the implications for the soil carbon balance of a rainfed olive grove under a dry Mediterranean climate. Agric. Ecosyst. Environ. 2014, 196, 167-177. [CrossRef]

18. Cerdà, A.; Rodrigo-Comino, J.; Giménez-Morera, A.; Keesstra, S.D. An economic, perception and biophysical approach to the use of oat straw as mulch in Mediterranean rainfed agriculture land. Ecol. Eng. 2017, 108, 162-171. [CrossRef]

19. Parras-Alcántara, L.; Lozano-García, B.; Keesstra, S.; Cerdà, A.; Brevik, E.C. Long-term effects of soil management on ecosystem services and soil loss estimation in olive grove top soils. Sci. Total Environ. 2016, 571, 498-506. [CrossRef] [PubMed]

20. Lozano-García, B.; Parras-Alcántara, L.; Albornoz, M.D.T.C.D. Effects of oil mill wastes on surface soil properties, runoff and soil losses in traditional olive groves in southern Spain. Catena 2011, 85, 187-193. [CrossRef]

21. Martinez-Mena, M.; López, J.; Almagro, M.; Boix-Fayos, C.; Albaladejo, J. Effect of water erosion and cultivation on the soil carbon stock in a semiarid area of South-East Spain. Soil Tillage Res. 2008, 99, 119-129. [CrossRef]

22. Rodrigo-Comino, J.; Taguas, E.; Seeger, M.; Ries, J.B. Quantification of soil and water losses in an extensive olive orchard catchment in Southern Spain. J. Hydrol. 2018, 556, 749-758. [CrossRef]

23. Kummu, M.; de Moel, H.; Porkka, M.; Siebert, S.; Varis, O.; Ward, P. Lost food, wasted resources: Global food supply chain losses and their impacts on freshwater, cropland, and fertiliser use. Sci. Total Environ. 2012, 438, 477-489. [CrossRef]

24. Cerdà, A.; Rodrigo-Comino, J.; Giménez-Morera, A.; Novara, A.; Pulido, M.; Kapović-Solomun, M.; Keesstra, S. Policies can help to apply successful strategies to control soil and water losses. The case of chipped pruned branches (CPB) in Mediterranean citrus plantations. Land Use Policy 2018, 75, 734-745. [CrossRef]

25. Lee, H.; Lautenbach, S.; Nieto, A.P.G.; Bondeau, A.; Cramer, W.; Geijzendorffer, I.R. The impact of conservation farming practices on Mediterranean agro-ecosystem services provisioning-A meta-analysis. Reg. Environ. Chang. 2019, 19, 2187-2202. [CrossRef]

26. Montanaro, G.; Nuzzo, V.; Xiloyannis, C.; Dichio, B. Climate change mitigation and adaptation in agriculture: The case of the olive. J. Water Clim. Chang. 2018, 9, 633-642. [CrossRef]

27. European Commission. Communication from the Commission to the European Parliament, the Council, the European Economic and Social Committee and the Committee of the Regions. A Farm to Fork Strategy; COM (2020)381 final; European Commission: Brussels, Belgium, 2020.

28. Maaya, L.; Meulders, M.; Surmont, N.; Vandebroek, M. Effect of Environmental and Altruistic Attitudes on Willingness-to-Pay for Organic and Fair Trade Coffee in Flanders. Sustainability 2018, 10, 4496. [CrossRef]

29. Vapa-Tankosić, J.; Ignjatijević, S.; Kranjac, M.; Lekić, S.; Prodanović, R. Willingness to pay for organic products on the Serbian market. Int. Food Agribus. Manag. Rev. 2018, 21, 791-801. [CrossRef]

30. MAGRAMA. Anuario de Estadística 2018 [2018 Statistical Yearbook]; Ministerio de Agricultura, Alimentación y Medio Ambiente: Madrid, Spain, 2018.

31. Calatrava, J.; Franco, J.A. Using pruning residues as mulch: Analysis of its adoption and process of diffusion in Southern Spain olive orchards. J. Environ. Manag. 2011, 92, 620-629. [CrossRef]

32. Gómez-Limón, J.A.; Arriaza, M. Evaluación de la Sostenibilidad de las Explotaciones de Olivar en Andalucía; Analistas Económicos de Andalucía: Málaga, Spain, 2011.

33. Gómez-López, M.D.; Martínez-Granados, D.; Calatrava, J. Deliverable 2.Outcomes of the Multicriteria Model for Decision Making; EU Horizon 2020 DIVERFARMING Project, Grant Agreement N 728003; Universidad Politécnica de Cartagena: Cartagena, Spain, 2019.

34. Munda, G.; Nijkamp, P.; Rietveld, P. Information precision and evaluation methods. In Efficiency in the Public Sector; Giardina, E., Williams, A., Eds.; Edward Elgar: Cheltenham, UK, 1993; pp. 43-64.

35. Sturgis, P.; Roberts, C.; Smith, P. Middle Alternatives Revisited: How the neither/nor Response Acts as a Way of Saying “I Don't Know"? Sociol. Methods Res. 2014, 43, 15-38. [CrossRef]

36. Hwang, C.-L.; Yoon, K. Multiple Attribute Decision Making. In Lecture Notes in Economics and Mathematical Systems; Springer: Berlin/Heidelberg, Germany, 1981; Volume 186. [CrossRef]

37. Zeleny, M. Multiple Criteria Decision-Making; McGraw-Hill: New York, NY, USA, 1982.

38. Lai, Y.-J.; Liu, T.-Y.; Hwang, C.-L. TOPSIS for MODM. Eur. J. Oper. Res. 1994, 76, 486-500. [CrossRef]

39. Vicente-Vicente, J.L.; García-Ruiz, R.; Francaviglia, R.; Aguilera, E.; Smith, P. Soil carbon sequestration rates under Mediterranean woody crops using recommended management practices: A meta-analysis. Agric. Ecosyst. Environ. 2016, 235, 204-214. [CrossRef]

40. Gomez, J.A.; Alvarez, S.; Soriano, M.-A. Development of a soil degradation assessment tool for organic olive groves in southern Spain. Catena 2009, 79, 9-17. [CrossRef]

41. Martínez-Mena, M.; Carrillo-López, E.; Boix-Fayos, C.; Almagro, M.; Franco, N.G.; Díaz-Pereira, E.; Montoya, I.; De Vente, J. Long-term effectiveness of sustainable land management practices to control runoff, soil erosion, and nutrient loss and the role of rainfall intensity in Mediterranean rainfed agroecosystems. Catena 2020, 187, 104352. [CrossRef]

42. Cerdà, A.; Rodrigo-Comino, J.; Giménez-Morera, A.; Keesstra, S.D. Hydrological and erosional impact and farmer's perception on catch crops and weeds in citrus organic farming in Canyoles river watershed, Eastern Spain. Agric. Ecosyst. Environ. 2018, 258, 49-58. [CrossRef]

43. Areal, F.J.; Riesgo, L. Farmers' views on the future of olive farming in Andalusia, Spain. Land Use Policy 2014, $36,543-553$. [CrossRef] 
44. Bonet, A. Secondary succession of semi-arid Mediterranean old-fields in south-eastern Spain: Insights for conservation and restoration of degraded lands. J. Arid. Environ. 2004, 56, 213-233. [CrossRef]

45. De Graaff, J.; Zuazo, V.-H.D.; Jones, N.; Fleskens, L. Olive production systems on sloping land: Prospects and scenarios. J. Environ. Manag. 2008, 89, 129-139. [CrossRef]

46. Carpio, A.J.; Oteros, J.; Tortosa, F.S.; Guerrero-Casado, J. Land use and biodiversity patterns of the herpetofauna: The role of olive groves. Acta Oecologica 2016, 70, 103-111. [CrossRef]

47. Rey, P.J.; Manzaneda, A.J.; Valera, F.; Alcántara, J.M.; Tarifa, R.; Isla, J.; Molina-Pardo, J.L.; Calvo, G.; Salido, T.; Gutiérrez, J.E.; et al. Landscape-moderated biodiversity effects of ground herb cover in olive groves: Implications for regional biodiversity conservation. Agric. Ecosyst. Environ. 2019, 277, 61-73. [CrossRef]

48. Moreno-De-Las-Heras, M.; Lindenberger, F.; Latron, J.; Lana-Renault, N.; Llorens, P.; Arnáez, J.; Romero-Díaz, A.; Gallart, F. Hydro-geomorphological consequences of the abandonment of agricultural terraces in the Mediterranean region: Key controlling factors and landscape stability patterns. Geomorphology 2019, 333, 73-91. [CrossRef]

49. Rodrigo-Comino, J.; Martínez-Hernández, C.; Iserloh, T.; Cerdà, A. Contrasted Impact of Land Abandonment on Soil Erosion in Mediterranean Agriculture Fields. Pedosphere 2018, 28, 617-631. [CrossRef]

50. Romero-Díaz, A.; Ruiz-Sinoga, J.D.; Robledano-Aymerich, F.; Brevik, E.C.; Cerdà, A. Ecosystem responses to land abandonment in Western Mediterranean Mountains. Catena 2017, 149, 824-835. [CrossRef]

51. Kurtzman, D.; Shapira, R.H.; Bar-Tal, A.; Fine, P.; Russo, D. Nitrate fluxes to groundwater under citrus orchards in a Mediterranean climate: Observations, calibrated models, simulations and agro-hydrological conclusions. J. Contam. Hydrol. 2013, 151, 93-104. [CrossRef] [PubMed]

52. Qin, W.; Assinck, F.B.; Heinen, M.; Oenema, O. Water and nitrogen use efficiencies in citrus production: A meta-analysis. Agric. Ecosyst. Environ. 2016, 222, 103-111. [CrossRef]

53. Lidón, A.L.; Ramos, C.; Ginestar, D.; Contreras, W. Assessment of LEACHN and a simple compartmental model to simulate nitrogen dynamics in citrus orchards. Agric. Water Manag. 2013, 121, 42-53. [CrossRef]

54. Gonzalez-Andujar, J.L. Expert system for pests, diseases and weeds identification in olive crops. Expert Syst. Appl. 2009, 36, 3278-3283. [CrossRef]

55. Ollero-Lara, A.; Agustí-Brisach, C.; Lovera, M.; Roca, L.F.; Arquero, O.; Trapero, A. Field susceptibility of almond cultivars to the four most common aerial fungal diseases in southern Spain. Crop. Prot. 2019, 121, 18-27. [CrossRef]

56. Tena, A.; Garcia Marí, F. Current situation of citrus pests and diseases in the Mediterranean Basin. IOBC/Wprs Bull. 2011, 62, 365-378.

57. Garcerá, C.; Moltó, E.; Chueca, P. Spray pesticide applications in Mediterranean citrus orchards: Canopy deposition and off-target losses. Sci. Total Environ. 2017, 599-600, 1344-1362. [CrossRef] [PubMed]

58. Fernández-Romero, M.L.; Lozano-García, B.; Parras-Alcántara, L.; Collins, C.D.; Clark, J.M. Effects of Land Management on Different Forms of Soil Carbon in Olive Groves in Mediterranean Areas. Land Degrad. Dev. 2016, 27, 1186-1195. [CrossRef]

59. Sánchez-Moreno, S.; Castro, J.; Alonso-Prados, E.; Alonso-Prados, J.L.; García-Baudín, J.M.; Talavera, M.; Durán-Zuazo, V.H. Tillage and herbicide decrease soil biodiversity in olive orchards. Agron. Sustain. Dev. 2015, 35, 691-700. [CrossRef]

60. Martin-Gorriz, B.; Maestre-Valero, J.F.; Almagro, M.; Boix-Fayos, C.; Martínez-Mena, M. Carbon emissions and economic assessment of farm operations under different tillage practices in organic rainfed almond orchards in semiarid Mediterranean conditions. Sci. Hortic. 2020, 261, 108978. [CrossRef]

61. Torres-Miralles, M.; Grammatikopoulou, I.; Rescia, A. Employing contingent and inferred valuation methods to evaluate the conservation of olive groves and associated ecosystem services in Andalusia (Spain). Ecosyst. Serv. 2017, 26, 258-269. [CrossRef]

62. Lázaro, A.; Alomar, D. Landscape heterogeneity increases the spatial stability of pollination services to almond trees through the stability of pollinator visits. Agric. Ecosyst. Environ. 2019, 279, 149-155. [CrossRef]

63. Xu, H.; Jia, L.; Zhang, J.; Wei, Y. Combined effects of tillage direction and slope gradient on soil translocation by hoeing. Catena 2019, 175, 421-429. [CrossRef]

64. Álvarez-Mozos, J.; Campo, M.Á.; Giménez, R.; Casalí, J.; Leibar, U. Implications of scale, slope, tillage operation and direction in the estimation of surface depression storage. Soil Tillage Res. 2011, 111, 142-153. [CrossRef]

65. Di Prima, S.; Rodrigo-Comino, J.; Novara, A.; Iovino, M.; Pirastru, M.; Keesstra, S.; Cerdà, A. Soil Physical Quality of Citrus Orchards Under Tillage, Herbicide, and Organic Managements. Pedosphere 2018, 28, 463-477. [CrossRef]

66. López-Garrido, R.; Madejón, E.; León-Camacho, M.; Girón, I.; Moreno, F.; Murillo, J.M. Reduced tillage as an alternative to no-tillage under Mediterranean conditions: A case study. Soil Tillage Res. 2014, 140, 40-47. [CrossRef]

67. López-Garrido, R.; Madejón, E.; Moreno, F.; Murillo, J. Conservation Tillage Influence on Carbon Dynamics Under Mediterranean Conditions. Pedosphere 2014, 24, 65-75. [CrossRef]

68. Morugán-Coronado, A.; García-Orenes, F.; Cerdà, A. Changes in soil microbial activity and physicochemical properties in agricultural soils in Eastern Spain. Span. J. Soil Sci. 2015, 5, 201-213. [CrossRef]

69. Martínez-Mena, M.; Garcia-Franco, N.; Almagro, M.; Ruiz-Navarro, A.; Albaladejo, J.C.; De Aguilar, J.M.; Gonzalez, D.; Querejeta, J.I. Decreased foliar nitrogen and crop yield in organic rainfed almond trees during transition from reduced tillage to no-tillage in a dryland farming system. Eur. J. Agron. 2013, 49, 149-157. [CrossRef]

70. Mellouli, H.; Van Wesemael, B.; Poesen, J.; Hartmann, R. Evaporation losses from bare soils as influenced by cultivation techniques in semi-arid regions. Agric. Water Manag. 2000, 42, 355-369. [CrossRef] 
71. Cantalice, J.; Melo, R.; Silva, Y.; Filho, M.C.; Araujo, A.; Vieira, L.; Bezerra, S.; Barros, G.; Singh, V.P. Hydraulic roughness due to submerged, emergent and flexible natural vegetation in a semiarid alluvial channel. J. Arid. Environ. 2015, 114, 1-7. [CrossRef]

72. Kervroëdan, L.; Armand, R.; Saunier, M.; Ouvry, J.-F.; Faucon, M.-P. Plant functional trait effects on runoff to design herbaceous hedges for soil erosion control. Ecol. Eng. 2018, 118, 143-151. [CrossRef]

73. Liu, H.; Yao, L.; Lin, C.; Wang, X.; Xu, W.; Wang, H. 18-year grass hedge effect on soil water loss and soil productivity on sloping cropland. Soil Tillage Res. 2018, 177, 12-18. [CrossRef]

74. Bastida, F.; Jindo, K.; Moreno, J.L.; Hernández, T.; Garcia, C.; Moreno-Ortego, J.L. Effects of organic amendments on soil carbon fractions, enzyme activity and humus-enzyme complexes under semi-arid conditions. Eur. J. Soil Biol. 2012, 53, 94-102. [CrossRef]

75. López, R.; Burgos, P.; Hermoso, J.M.; Hormaza, J.I.; González-Fernández, J.J. Long term changes in soil properties and enzyme activities after almond shell mulching in avocado organic production. Soil Tillage Res. 2014, 143, 155-163. [CrossRef]

76. Parras-Alcántara, L.; Díaz-Jaimes, L.; Lozano-García, B. Organic Farming Affects C and N in Soils Under Olive Groves in Mediterranean Areas. Land Degrad. Dev. 2015, 26, 800-806. [CrossRef]

77. Vignozzi, N.; Agnelli, A.E.; Brandi, G.; Gagnarli, E.; Goggioli, D.; Lagomarsino, A.; Pellegrini, S.; Simoncini, S.; Simoni, S.; Valboa, G.; et al. Soil ecosystem functions in a high-density olive orchard managed by different soil conservation practices. Appl. Soil Ecol. 2019, 134, 64-76. [CrossRef]

78. Garcia-Franco, N.; Albaladejo, J.; Almagro, M.; Martínez-Mena, M. Beneficial effects of reduced tillage and green manure on soil aggregation and stabilization of organic carbon in a Mediterranean agroecosystem. Soil Tillage Res. 2015, 153, 66-75. [CrossRef]

79. Vicente-Vicente, J.; Gómez-Muñoz, B.; Hinojosa-Centeno, M.; Smith, P.; Garcia-Ruiz, R. Carbon saturation and assessment of soil organic carbon fractions in Mediterranean rainfed olive orchards under plant cover management. Agric. Ecosyst. Environ. 2017, 245, 135-146. [CrossRef]

80. Khan, Y.; Haque, M.; Molla, A.H.; Rahman, M.; Alam, M.Z. Antioxidant compounds and minerals in tomatoes by Trichodermaenriched biofertilizer and their relationship with the soil environments. J. Integr. Agric. 2017, 16, 691-703. [CrossRef]

81. Pellegrino, E.; Bedini, S. Enhancing ecosystem services in sustainable agriculture: Biofertilization and biofortification of chickpea (Cicer arietinum L.) by arbuscular mycorrhizal fungi. Soil Biol. Biochem. 2014, 68, 429-439. [CrossRef]

82. Rodrigues, M.Â.; Ladeira, L.C.; Arrobas, M. Azotobacter-enriched organic manures to increase nitrogen fixation and crop productivity. Eur. J. Agron. 2018, 93, 88-94. [CrossRef]

83. Simpson, R.J.; Oberson, A.; Culvenor, R.A.; Ryan, M.H.; Veneklaas, E.J.; Lambers, H.; Lynch, J.P.; Ryan, P.R.; Delhaize, E.; Smith, F.A.; et al. Strategies and agronomic interventions to improve the phosphorus-use efficiency of farming systems. Plant Soil 2011, 349, 89-120. [CrossRef]

84. Ramakrishna, W.; Yadav, R.; Li, K. Plant growth promoting bacteria in agriculture: Two sides of a coin. Appl. Soil Ecol. 2019, 138, 10-18. [CrossRef]

85. Ryan, M.H.; Graham, J.H. Little evidence that farmers should consider abundance or diversity of arbuscular mycorrhizal fungi when managing crops. New Phytol. 2018, 220, 1092-1107. [CrossRef] [PubMed]

86. European Union. Regulation (EU) No 1305/2013 of the European Parliament and of the Council of 17 December 2013 on Support for Rural Development by the European Agricultural Fund for Rural Development (EAFRD) and Repealing Council Regulation (EC) No 1698/2005; European Union: Brussels, Belgium, 2013.

87. Knierim, A.; Kernecker, M.; Erdle, K.; Kraus, T.; Borges, F.; Wurbs, A. Smart farming technology innovations-Insights and reflections from the German Smart-AKIS hub. NJAS Wagening J. Life Sci. 2019, 90-91, 100314. [CrossRef]

88. European Commission. Communication from the Commission to the European Parliament, the Council, the European Economic and Social Committee and the Committee of the Regions The Future of Food and Farming; COM (2017)713 final; European Commission: Brussels, Belgium, 2017.

89. Kernecker, M.; Knierim, A.; Wurbs, A.; Kraus, T.; Borges, F. Experience versus expectation: Farmers' perceptions of smart farming technologies for cropping systems across Europe. Precis. Agric. 2020, 21, 34-50. [CrossRef]

90. Long, T.B.; Blok, V.; Coninx, I. Barriers to the adoption and diffusion of technological innovations for climate-smart agriculture in Europe: Evidence from the Netherlands, France, Switzerland and Italy. J. Clean. Prod. 2016, 112, 9-21. [CrossRef]

91. Yeomans, P.A. The Keyline Plan; P.A. Yeomans: Sydney, Australia, 1954.

92. Zornoza, R.; Acosta, J.A.; Gabarrón, M.; Gómez-Garrido, M.; Sánchez-Navarro, V.; Terrero, A.; Martínez-Martínez, S.; Faz, Á.; Pérez-Pastor, A. Greenhouse gas emissions and soil organic matter dynamics in woody crop orchards with different irrigation regimes. Sci. Total Environ. 2018, 644, 1429-1438. [CrossRef] [PubMed]

93. Pastor, A.P.; Ruiz-Sánchez, M.C.; Domingo, R. Effects of timing and intensity of deficit irrigation on vegetative and fruit growth of apricot trees. Agric. Water Manag. 2014, 134, 110-118. [CrossRef]

94. Martínez-Granados, D.; Calatrava, J. Conocimiento y percepción sobre técnicas de riego deficitario controlado por parte de agricultores y técnicos agrarios del sudeste español. Inf. Tec. Econ. Agrar. 2020. [CrossRef]

95. Pazienza, P.; De Lucia, C. For a new plastics economy in agriculture: Policy reflections on the EU strategy from a local perspective. J. Clean. Prod. 2020, 253, 119844. [CrossRef]

96. Payne, J.; McKeown, P.; Jones, M.D. A circular economy approach to plastic waste. Polym. Degrad. Stab. 2019, 165, 170-181. [CrossRef] 